\title{
Glycerol dialkyl glycerol tetraethers (GDGTs) in high latitude Siberian permafrost: Diversity, environmental controls, and implications for proxy applications
}

\author{
Stephanie Kusch $^{\mathrm{a}, *}$, Maria Winterfeld ${ }^{\mathrm{b}}$, Gesine Mollenhauer ${ }^{\mathrm{b}}$, Silke T. Höfle ${ }^{\mathrm{a}}$, Lutz Schirrmeister ${ }^{\mathrm{c}}$, \\ Georg Schwamborn ${ }^{\mathrm{d}}$, Janet Rethemeyer ${ }^{\mathrm{a}}$ \\ ${ }^{a}$ Institute of Geology and Mineralogy, University of Cologne, Zülpicher Str. 49b, 50674 Cologne, Germany \\ ${ }^{\mathrm{b}}$ Alfred Wegener Institute Helmholtz Centre for Polar and Marine Research, Section of Marine Geochemistry, Am Handelshafen 12,27570 Bremerhaven, Germany \\ ${ }^{\mathrm{c}}$ Alfred Wegener Institute Helmholtz Centre for Polar and Marine Research, Section of Permafrost Research, Telegrafenberg, A45, 14473 Potsdam, Germany

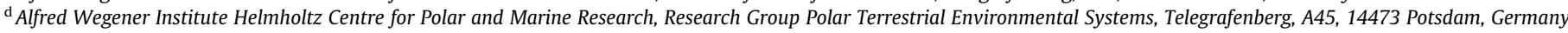

\section{A R T I C L E I N F O}

\section{Article history:}

Received 31 March 2019

Received in revised form 31 May 2019

Accepted 25 June 2019

Available online 28 June 2019

\section{Keywords:}

Glycerol dialkyl glycerol tetraethers

High latitude

Siberia

Permafrost

Soil

pH calibration

\section{A B S T R A C T}

Archaeal and bacterial glycerol dialkyl glycerol tetraethers (GDGTs) are globally abundant in soils under various climatic conditions, but little is known about their sources, relative distribution, and environmental controls on their diversity in high latitude permafrost deposits. Thus, constraints on GDGT-based proxies, such as methylation of branched GDGTs (MBT) or cyclization of branched GDGTs (CBT) used to infer mean annual temperature or soil pH, are also sparse. We investigated the GDGT diversity in typical North Siberian permafrost deposits including the active layer of polygonal tundra soils (seasonally frozen ground), fluvial terrace/floodplain sediments, Holocene and Pleistocene thermokarst sediments, and late Pleistocene Ice Complex (Yedoma). Our data show that isoprenoid GDGTs are produced by both methanotrophic and methanogenic Euryarchaeota, as well as Thaumarchaeota, but their abundance does not seem to be controlled by the investigated physicochemical parameters including \%TOC, \%TN, and soil pH. Branched GDGTs (brGDGTs) show similar distributional changes to those observed in other high latitude soil samples, i.e., a dominance of pentamethylated and hexamethylated brGDGTs, likely reflecting the adaptation to low temperatures and a positive correlation of the degree of cyclization with soil $\mathrm{pH}$. Specifically, brGDGT-IIIa correlates positively with \%TOC and \%TN and negatively with soil pH, while brGDGT-Ib and brGDGT-IIb correlate negatively with \%TOC and \%TN and positively with pH. Moreover, we observe a negative correlation between 5-methyl and 6-methyl brGDGTs without cyclopentane moieties (except brGDGT-IIIa), but this anticorrelation does not seem to be related to the investigated physicochemical parameters. The observed brGDGT distribution yields a permafrost-specific soil $\mathrm{pH}$ calibration, $p H_{P F}^{\prime}=1.8451 \times C^{\prime} T^{\prime}{ }_{P F}+8.5396\left(r^{2}=0.60\right.$, RMSE $\left.=0.074 ; \mathrm{n}=109\right)$.

The different investigated deposit types show some distinct GDGT distributional changes and appear to be distinguishable based on the relative abundance of crenarchaeol, GDGT-0/(crenarchaeol + GDGT-0) ratios, and $\mathrm{CBT}_{\mathrm{PF}}$ values, although we also observe strong heterogeneity for each deposit type. In particular, Yedoma and the active layer of polygonal tundra soils represent distinct endmembers, which differ from each other, as well as from fluvial terrace/floodplain sediments and thermokarst sediments, while the latter two deposit types have similar GDGT fingerprints that are not easily distinguishable. Yet, the observed GDGT distributional differences have implications for GDGT proxies analyzed in aquatic suspended matter and sediments. Quantitative estimates of permafrost erosion, as well as soil pH inferred using BIT indices or $\mathrm{CBT}_{\mathrm{PF}}$, respectively, may be biased by changing relative contributions of different deposit types (carrying their respective GDGT signals) to the exported permafrost OC, particularly from Yedoma and the active layer of polygonal tundra soils.

(c) 2019 Elsevier Ltd. All rights reserved.

\footnotetext{
* Corresponding author.
}

\section{Introduction}

Glycerol dialkyl glycerol tetraethers (GDGTs; Appendix A) constitute the microbial cell membrane monolayer and are produced 
either with isoprenoid alkyl chains (isoGDGTs) by archaea, or with methyl-branched alkyl chains (brGDGTs) by bacteria (Schouten et al., 2013). IsoGDGTs are synthesized by a range of archaeal phylogenetic groups, but crenarchaeol and its isomer, isoGDGTs with four cyclopentane and one cyclohexane moiety, have only been found in autotrophic ammonia oxidizing Thaumarchaeota. They are thus useful chemotaxonomic markers for this phylogenetic group (Schouten et al., 2013 and references therein). Heterotrophic Acidobacteria are considered the tentative source of brGDGTs (Weijers et al., 2010). However, Sinninghe Damsté et al. (2018) recently argued that the search for the biological source of brGDGTs should be extended to other bacterial phyla since: (i) so far only a limited amount of acidobacterial strains have been shown to produce brGDGTs or iso-diabolic acid (the potential building block for brGDGTs) and (ii) all environmental acidobacterial metagenomes, as well as all but one cultured acidobacterial strain, lack a newly identified gene cluster tentatively coding for the ether bond between iso-diabolic acid and glycerol (Sinninghe Damsté et al., 2018). Both classes of GDGTs occur with different numbers of cyclic and/or methyl moieties in the alkyl chains and the relative abundance of these moieties has been shown to vary with environmental parameters such as temperature (Methylation of Branched Tetraethers; MBT) and pH (Cyclization of Branched Tetraethers; CBT), making GDGTs useful paleoenvironmental proxies (Schouten et al., 2002; Weijers et al., 2007).

Globally, soils have been shown to comprise a wide structural diversity of GDGTs (De Jonge et al., 2014; Weijers et al., 2006). For brGDGTs in soils, the global pattern reveals a correlation between the methylation of brGDGTs and mean annual air temperature, as well as the cyclization of brGDGTs and soil pH (De Jonge et al., 2014). Whether these environmental parameters also govern the brGDGT distribution in bacterial membranes at high latitudes $\left(<65^{\circ} \mathrm{N}\right)$, however, is poorly constrained. To date, our knowledge of GDGT diversity in high latitude soils is very limited owing to the low number of samples investigated from these areas and missing broader regional spatial coverage. The global soil data set of De Jonge et al. (2014) contains only 12 samples obtained from Svalbard, Greenland, and Iceland. These are complemented by 11 samples from Southwest Greenland (Colcord et al., 2015), 7 samples each from the Colville river catchment in Northern Alaska (Hanna et al., 2016) and the Yenisei catchment in Siberia (De Jonge et al., 2015), and one sample each from the Mackenzie and Kolyma river catchments in Canada and Siberia, respectively (Peterse et al., 2014). In addition, Bischoff et al. (2013) investigated GDGTs in 23 samples from a permafrost core recovered from Kurungnakh Island in the Lena Delta, Siberia, and Sparkes et al. (2015) investigated three samples from a Kolyma riverbank erosion profile. However, neither of these studies report detailed abundances of the full suite of GDGTs. Most of these high latitude studies do not include isoGDGT distributions but focus on brGDGT diversity and among these, however, only De Jonge et al. (2014) and De Jonge et al. (2015) report abundances of 5-methyl and 6methyl brGDGTs. In fact, many of the high latitude samples were obtained to provide the "soil" endmember when tracing the export of permafrost-derived organic carbon (OC) into aquatic sediments (Bischoff et al., 2016; De Jonge et al., 2015, 2016b; Dog rul Selver et al., 2015; Peterse et al., 2014; Sparkes et al., 2015). Thus, a comprehensive study of the GDGT diversity in high latitude soils and different permafrost deposits is still missing, restricting constraints on the environmental controls on GDGT distributions at high latitude.

Here, we present GDGT inventories and proxies of 129 permafrost samples from Arga Island, Samoylov Island, Kurungnakh Island, the Buor Khaya Peninsula, and Bol'shoy Lyakhovsky Island, representing typical North Siberian permafrost deposits including the active layer (the uppermost layer thawing during summer) of the polygonal tundra soils, Holocene fluvial terrace and floodplain sediments, Holocene and Eemian thermokarst sediments, and late Pleistocene Ice Complex (Yedoma). These deposit types have different origins including aquatic sedimentation, thermokarst, pedogenesis, and nival lithogenesis (e.g. Schirrmeister et al., 2011a, 2011b) and are characterized by different physicochemical properties, which are particularly expressed in total OC content and soil $\mathrm{pH}$ with ranges of $0.1-33.8 \%$ and $4.3-8.0$, respectively; the most prominent differences occurring in polygonal tundra soils and Yedoma. We use these data to investigate GDGT diversity among deposit types, constrain GDGT sources and environmental controls, and assess potential implications for GDGTbased proxies in aquatic sediments as used in (paleo)environmental studies.

\section{Material and methods}

\subsection{Site description and samples}

Samples were obtained from the Lena river delta including Arga Island, Samoylov Island, Kurungnakh Island, as well as from the Buor Khaya Peninsula and Bol'shoy Lyakhovsky Island (Fig. 1, Table S1). These samples represent typical Siberian permafrost deposits including active layer of polygonal tundra soils $(n=49)$, Holocene fluvial terrace/floodplain sediments $(n=21)$, Holocene thermokarst sediments $(n=9)$, and Late Pleistocene Yedoma $(n=43)$. In addition, a few samples represented glacial to Holocene cover deposits $(n=5)$ and late Pleistocene ice wedges $(n=2)$. Since the origin of these ('other') 7 samples cannot be further specified, we do not include the respective data when discussing deposit type specific GDGT distributions.

The active layer of polygonal tundra soils (referred to as active layer soils in the following), from the Lena Delta, were sampled from each of the three geomorphological units including Holocene fluvial deposits of the active delta (Samoylov Island), late Pleistocene to early Holocene fluvial sands (Arga Island), and late Pleistocene Ice Complex deposits covered by Holocene aeolian silty sand (Kurungnakh Island) (Schirrmeister et al., 2011a; Schwamborn et al., 2002). Drill core BK-8 was recovered from a Yedoma hill, which is composed of late Pleistocene Ice Complex deposits covered by Late Glacial and Holocene sands on the Buor Khaya Peninsula (Schirrmeister et al., 2017). Drill cores L14-02, L14-04, and L14-05 were retrieved from Bol'shoy Lyakhovsky Island. L14-02 includes a late Pleistocene Ice Complex sequence (MIS 3) while L14-04 and L14-05 represent interglacial thermokarst sediments from the Eemian (MIS 5) and interstadial deposits from the late Pleistocene (MIS 4 and MIS 3) and Holocene, respectively (Stapel et al., 2018). Each of the Buor Khaya Peninsula and Bol'shoy Lyakhovsky Island drill cores included an uppermost active layer soil. Detailed descriptions of the drill cores are given by Günther et al. (2013), Overduin (2015), Schirrmeister et al. (2017), Schwamborn and Wetterich (2016, 2015), Stapel et al. (2018, 2016), and Zimmermann et al. (2017a, 2017b).

\subsection{Methods}

\subsubsection{Bulk parameters}

For total organic carbon (\%TOC) measurements, $20-50 \mathrm{mg}$ of sample were reacted with $37 \% \mathrm{HCl}$ for $1 \mathrm{~h}$ at $250{ }^{\circ} \mathrm{C}$. Excess iron oxide and tungsten oxide were added and samples were analyzed using an ELTRA CS 2000 elemental analyzer. Total nitrogen (\%TN) was measured on $20-30 \mathrm{mg}$ sample after addition of $20 \mathrm{mg}$ tungsten trioxide as an oxidation catalyst using an Elementar Vario EL III elemental analyzer. Soil pH values were measured on sample splits after immersion in water (5:2 water:sample, v:v) for $60 \mathrm{~min}$ 


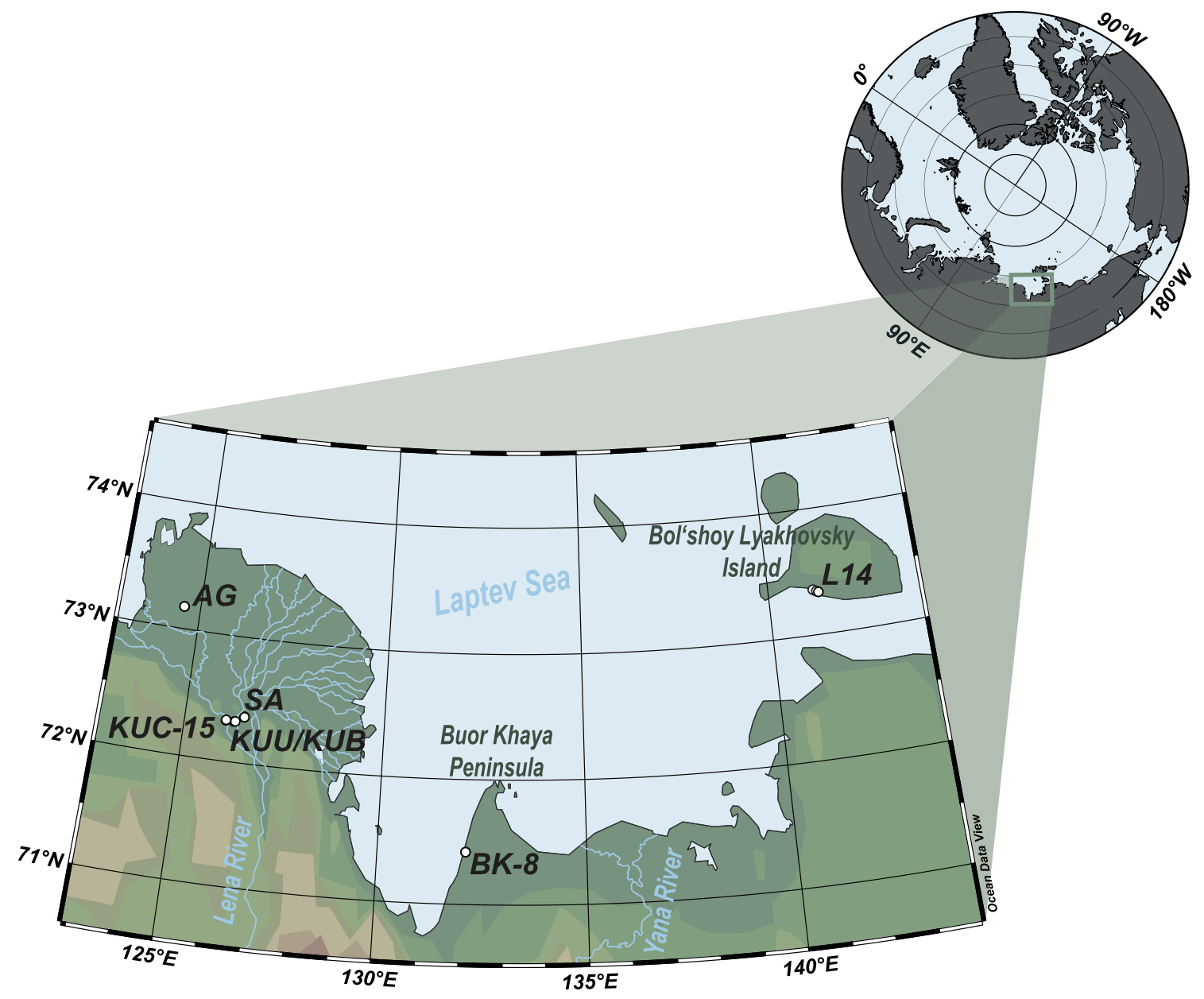

Fig. 1. Map of the study area and sample locations in Northern Yakutia, Siberia. Detailed sample information is given in Table S1.

using a Mettler Toledo FiveEasy $\mathrm{pH}$ meter and are reported as means of triplicate measurements. Bulk parameters for the Samoylov and Kurungnakh active layer soils were measured previously (Table S2; Höfle et al. 2015).

\subsubsection{Lipid analyses}

Depending on TOC content, GDGTs were extracted from 0.5 to $10 \mathrm{~g}$ of freeze-dried sample using either ultrasonication or accelerated solvent extraction (Thermo Fischer ASE 300; 120 bar and $120^{\circ} \mathrm{C}$ ) with a dichloromethane: methanol 9:1 (v: v) solvent mixture. Subsequently, the total lipid extract was saponified using $0.5 \mathrm{M}$ potassium hydroxide in methanol for $3 \mathrm{~h}$ at $85^{\circ} \mathrm{C}$. Neutral lipids were liquid-liquid extracted into hexane and separated into polarity fractions via silica gel column chromatography (1\% activated $\mathrm{SiO}_{2}, 0.063-0.2 \mathrm{~mm}$ mesh size). GDGTs eluted in methanol (Thienemann et al., 2017). The GDGT fraction was evaporated to dryness and GDGTs were filtered through a $0.45 \mu \mathrm{m}$ PTFE syringe filter using 95:5 ( $\mathrm{v}: \mathrm{v}$ ) hexane: isopropan-2-ol. GDGTs were analyzed using an Agilent 1290 UHPLC connected to a 6460 QQQ equipped with an APCI ion source and operated in SIM mode following the method described in Hopmans et al. (2016). Chromatographic separation was achieved on two serial Waters BEH HILIC columns $(2.1 \times 150 \mathrm{~mm}, 1.7 \mu \mathrm{m}$; Waters $)$ guarded by a corresponding $2.1 \times 5 \mathrm{~mm}$ pre-column. Solvents, solvent gradient, flow rate, and oven thermostat temperature were set following Hopmans et al. (2016). GDGTs were detected as $[\mathrm{M}+\mathrm{H}]^{+}$ions and quantified against an internal $\mathrm{C}_{46}$ GDGT standard (Huguet et al., 2006).

\subsection{Statistical analysis}

Principal component analysis (PCA) was performed using the PAST 3.16 (Hammer et al., 2001) software. Input data included GDGT fractional abundances, \%TOC and \%TN content, and pH values, all of which were standardized prior to running the PCA. PCA was performed separately for isoGDGTs $\left(\mathrm{PCA}_{\text {iso }}\right)$ and brGDGTs $\left(\mathrm{PCA}_{\mathrm{br}}\right)$.

\section{Results}

\subsection{Elemental parameters}

Elemental parameters for the different deposit types are shown in Fig. 2. \%TOC ranges from $0.1 \%$ to $33.8 \%$ and is highest in active layer soils (10.6 $\pm 10.0 \%$; mean \pm SD; Fig. $2 \mathrm{~A}$ ) and lowest in thermokarst sediments $(0.9 \pm 0.5 \%)$. Likewise, the \%TN is highest in active layer soils $(0.5 \pm 0.5 \%$; Fig. $2 \mathrm{~B})$ but is within $0.2 \pm 0.2 \%$ in all other deposit types, showing a total range from $0.0 \%$ to $1.9 \%$. Soil $\mathrm{pH}$ ranges from 4.3 to 8.0 in all samples. The highest soil $\mathrm{pH}$ was measured in Holocene fluvial terrace/floodplain sediments (6.8 \pm 0.8 ; Fig. 2C) although soil $\mathrm{pH}$ in thermokarst sediments $(6.6 \pm 0.6)$ and Yedoma $(6.7 \pm 0.8)$ is very similar. A significantly lower soil $\mathrm{pH}$ was determined for active layer soils (5.2 \pm 0.6$)$.

\subsection{GDGTs}

The average relative abundances of isoGDGTs and brGDGTs in the different permafrost deposit types are shown in Fig. 3. In gen- 

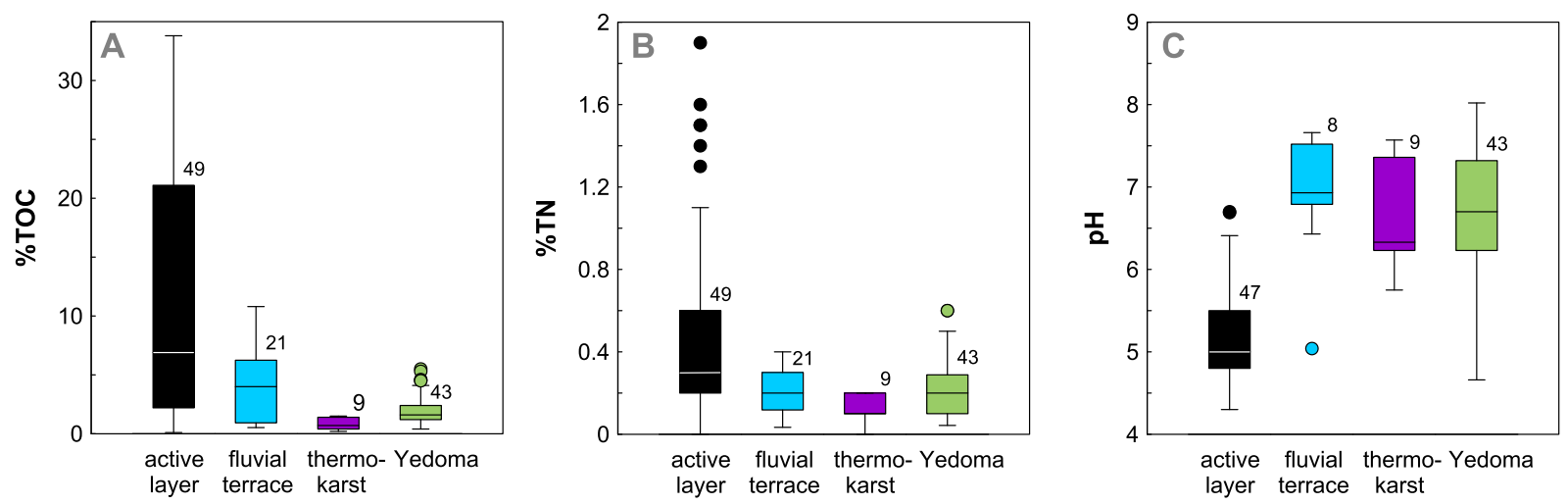

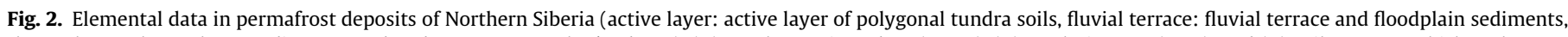

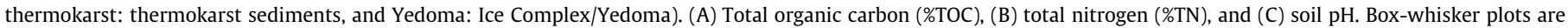
shown in Tukey style with IQR values of 1.5 ; numbers denote sample count.

eral, brGDGTs represent the majority of GDGTs in all deposits $(90.0 \pm 12.0 \%$; mean $\pm S D)$. Highest absolute brGDGT concentrations are found in active layer soils $(59.9 \pm 135.3 \mu \mathrm{g} / \mathrm{g}$ TOC; Fig. 3B) and the lowest concentrations are observed in Holocene fluvial terrace/floodplain sediments $(11.0 \pm 5.8 \mu \mathrm{g} / \mathrm{g}$ TOC). Likewise, the highest relative brGDGT abundances are also observed in active layer soils (95.4 $\pm 4.2 \%$; Fig. $3 \mathrm{C}$ ) and lowest abundances are detected in Holocene fluvial terrace/floodplain sediments ( $84.7 \pm 11.8 \%$; Fig. 3D). The Branched and Isoprenoid Tetraether (BIT) index, as defined by Hopmans et al. (2004), is highest in active layer soils $(1.00 \pm 0.01$; Fig. $4 \mathrm{E})$ and lowest in Yedoma $(0.91 \pm 0.12)$. The lowest BIT index was 0.52 in a Yedoma sample in core L14-02 (6.08-6.17 m).

Penta- and hexamethylated brGDGTs dominate in all deposit types accounting for, on average, $43.6 \pm 5.7 \%$ and $39.5 \pm 10.0 \%$, respectively (Fig. 3C-F), while tetramethylated brGDGTs only constitute an average of $16.8 \pm 6.1 \%$ of all brGDGTs. Among the pentaand hexamethylated brGDGTs, brGDGTs without cyclopentane moieties are most abundant, particularly brGDGT-IIIa and brGDGT-Ila, which account for $32.4 \pm 10.6 \%$ ( $7.9 \mathrm{ng} / \mathrm{g}$ TOC to $304.8 \mu \mathrm{g} / \mathrm{g}$ TOC) and $33.7 \pm 8.1 \%(15.0 \mathrm{ng} / \mathrm{g}$ TOC to $433.9 \mu \mathrm{g} / \mathrm{g}$ TOC) of all brGDGTs, respectively. Accordingly, the weighted average number of cyclopentane moieties (\#rings tetra $_{\text {, }}$ rings penta,5Me, $_{\text {, }}$

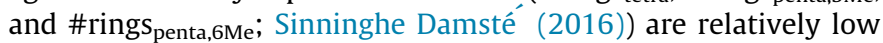
averaging $0.13 \pm 0.10,0.07 \pm 0.08$, and $0.12 \pm 0.13$, respectively, for all samples (Fig. 5D-F). Mean \#rings tetra \#rings penta,5Me, and

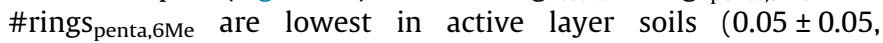
$0.03 \pm 0.03$, and $0.07 \pm 0.09$, respectively) while mean \#rings $s_{\text {tetra }}$ $(0.19 \pm 0.11)$ and \#rings penta,5Me $(0.12 \pm 0.11)$ are highest in Yedoma and \#rings penta,6Me $(0.24 \pm 0.25)$ is highest in thermokarst sediments.

The highest relative abundance of isoGDGTs is evident in Holocene fluvial terrace/floodplain sediments (15.3 $\pm 11.8 \%$; Fig. 3D), while active layer soils have the lowest relative abundance of isoGDGTs (4.6 $\pm 4.2 \%$; Fig. $3 C$ ). Late Pleistocene Yedoma shows the only significant relative abundance of crenarchaeol $(6.3 \pm 8.2 \%$; Fig. $3 \mathrm{~F})$. In contrast, absolute isoGDGT concentrations are highest in thermokarst sediments $(2.5 \pm 1.9 \mu \mathrm{g} / \mathrm{g}$ TOC; Fig. 3A) and lowest in active layer soils (mean $1.6 \pm 2.5 \mu \mathrm{g} / \mathrm{g}$ TOC). While the mean concentrations for the different deposit types agree within SD, the total isoGDGT concentrations in all samples span several orders of magnitude ranging from $3.0 \mathrm{ng} / \mathrm{g}$ TOC to $29.1 \mu \mathrm{g} / \mathrm{g}$ TOC. GDGT-0/crenarchaeol ratios (Fig. 4A) range from 0.3 to 2841.0 with means from $5.6 \pm 9.0$ in thermokarst sediments to $223.4 \pm 542.8$ in active layer soils. GDGT-2/crenarchaeol ratios range from 0.0 to 8.0 and are highest in active layer soils $(1.1 \pm 2.0)$ and lowest in thermokarst sediments $(0.2 \pm 0.1)$. The methane index (MI) as defined by Zhang et al. (2011) mirrors these distributions (Fig. 4C). While the samples show the full MI range $(0.0-1.0)$, mean values are highest in active layer soils $(0.63 \pm 0.34)$ and lowest in thermokarst sediments $(0.38 \pm 0.15)$.

\section{Discussion}

Bacterial and archaeal metabolic activity at subzero temperatures has been detected in laboratory incubation studies using stable isotope and radio isotope labelling techniques (Rivkina et al., 2004, 2007, 2000; Steven et al., 2007; Tuorto et al., 2014). Tuorto et al. (2014) showed that various bacterial species are active in both narrow and wide subzero temperature ranges, including members of the Acidobacteria, the tentative source of brGDGTs (Sinninghe Damsté et al., 2018, 2014, 2011). Accordingly, GDGTs in our permafrost samples could derive from active bacteria and archaea. However, under extreme conditions such as in permafrost the majority of GDGTs may simply be present due to exceptional preservation of labile compounds at subzero temperatures, similar to what has been observed for DNA (Willerslev et al., 2004). The activity detected during the exponential growth phase of incubation labelling studies may be stimulated by the addition of substrate causing an artificial nutrient effect. This may not occur under natural conditions, which lack influx of energy sources (Rivkina et al., 2000).

While we consider the majority of GDGTs in active layer soils to derive from metabolically active microbes, our data set does not allow us to distinguish contributions of GDGTs from metabolically active soil microbes and freeze-locked GDGTs preserved over glacial-interglacial timescales, such as in fluvial terrace/floodplain sediments, thermokarst sediments, and Yedoma. Accordingly, we cannot estimate the effect of the archaeal and bacterial metabolic state on GDGT proxies in these samples, but we expect that the metabolic origin does affect brGDGT-based temperature estimates, for example, if bacteria are currently active in deposits accumulated during warmer mean air temperatures (MAT) such as the Eemian thermokarst lake sediments in core L14-04. As per mass balance, the effect might be significant even at basal metabolic rates if the activity happens over prolonged timescales. In addition, linking brGDGT abundances to MAT would also be hampered by (i) the uncertainty of past MATs allowing only current active layer soils to be used, (ii) the small MAT gradient across the study area, and (iii) the uncertainty as to how seasonally biased the recorded GDGT MAT signal is. Thus, we will refrain from linking GDGT distributions to MAT. However, irrespective of whether GDGTs represent active microbes or preserved cell membrane lipids, their relative and absolute abundances can still be linked to the 

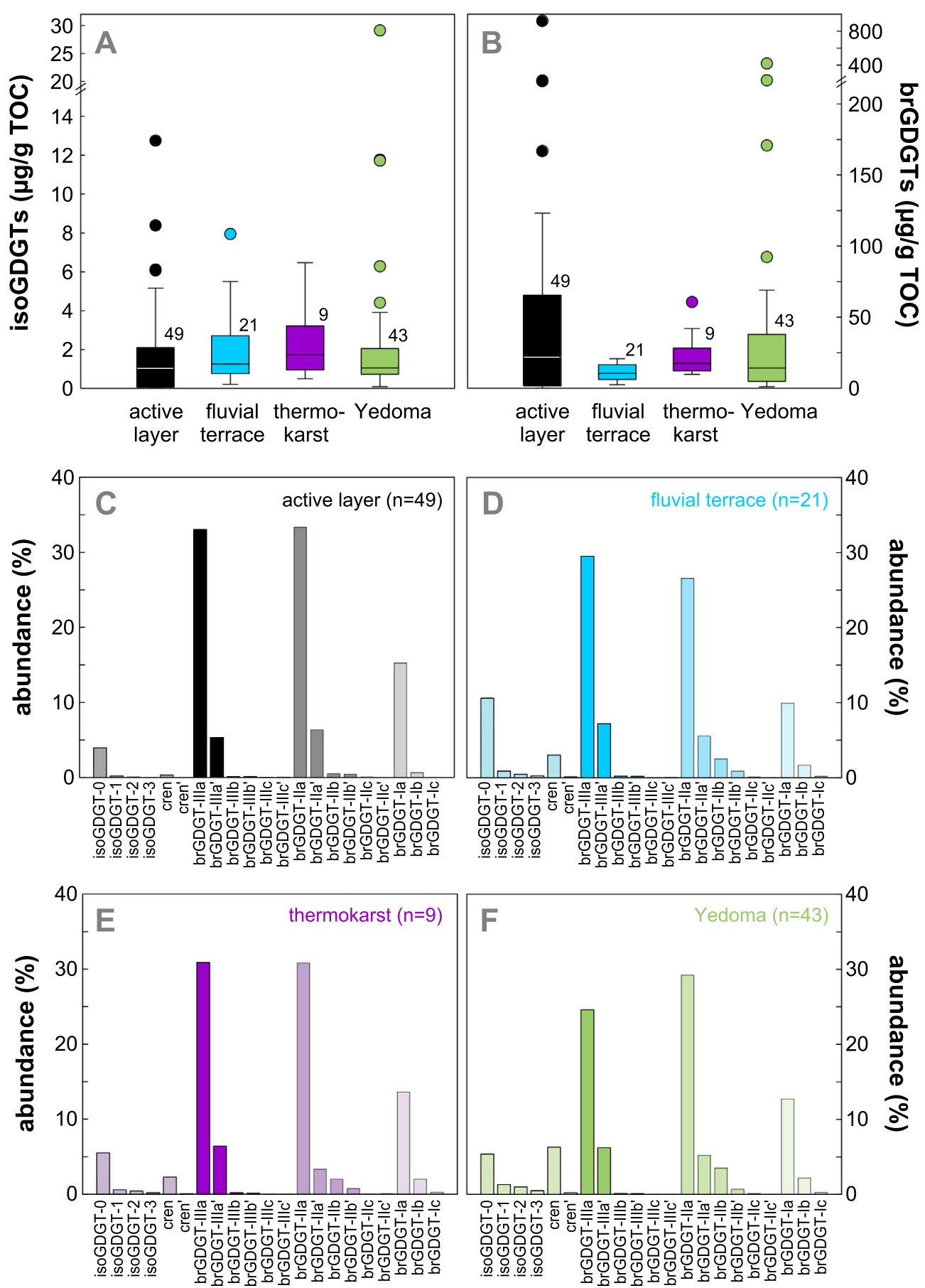

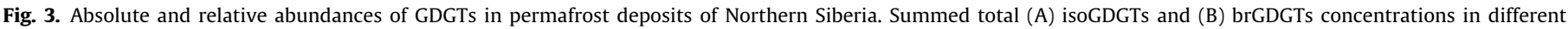

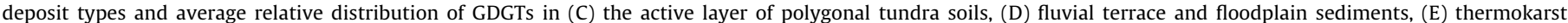

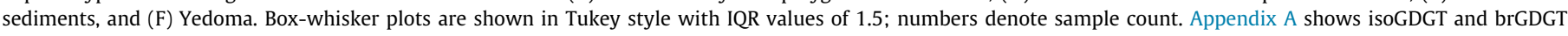
structures.

respective permafrost deposit type and its basic physicochemical properties including \%TOC, \%TN, and soil $\mathrm{pH}$, which result from complex interactions including (but not limited to) the mineralogy of the parent material, the state of decomposition and pedogenesis, current microbial and vegetation feedbacks (in case of active layer soils), and climatic conditions and are, thus, highly variable between samples and deposit types (Fig. 2). Active layer soils are currently open systems, while the physicochemical properties of the other deposit types represent time-integrated signals of past environmental conditions, which are not constrained. Here, we make the simplified assumption that in the absence of diffusive transport of compounds and ions in pore waters, the physicochemical parameters (\%TOC, \%TN, and $\mathrm{pH}$ ) of the perennially frozen samples have not changed significantly since they were frozen permanently (closed system assumption) including after thermokarst or Taberite (thawed and refrozen Yedoma) development. 

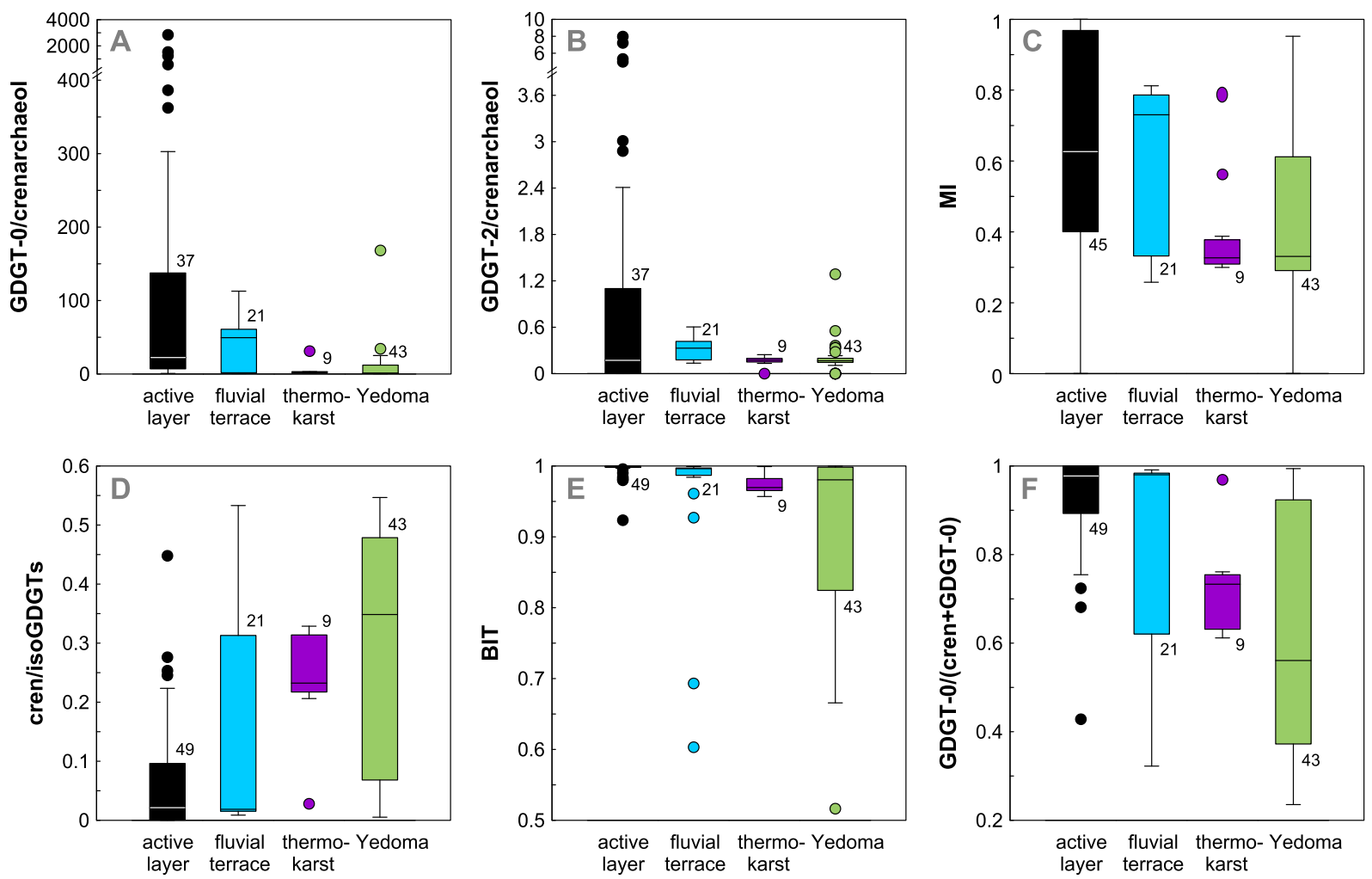

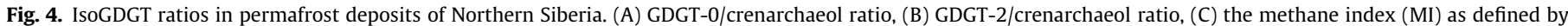

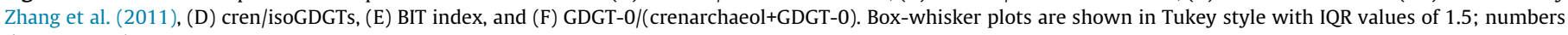
denote sample count.
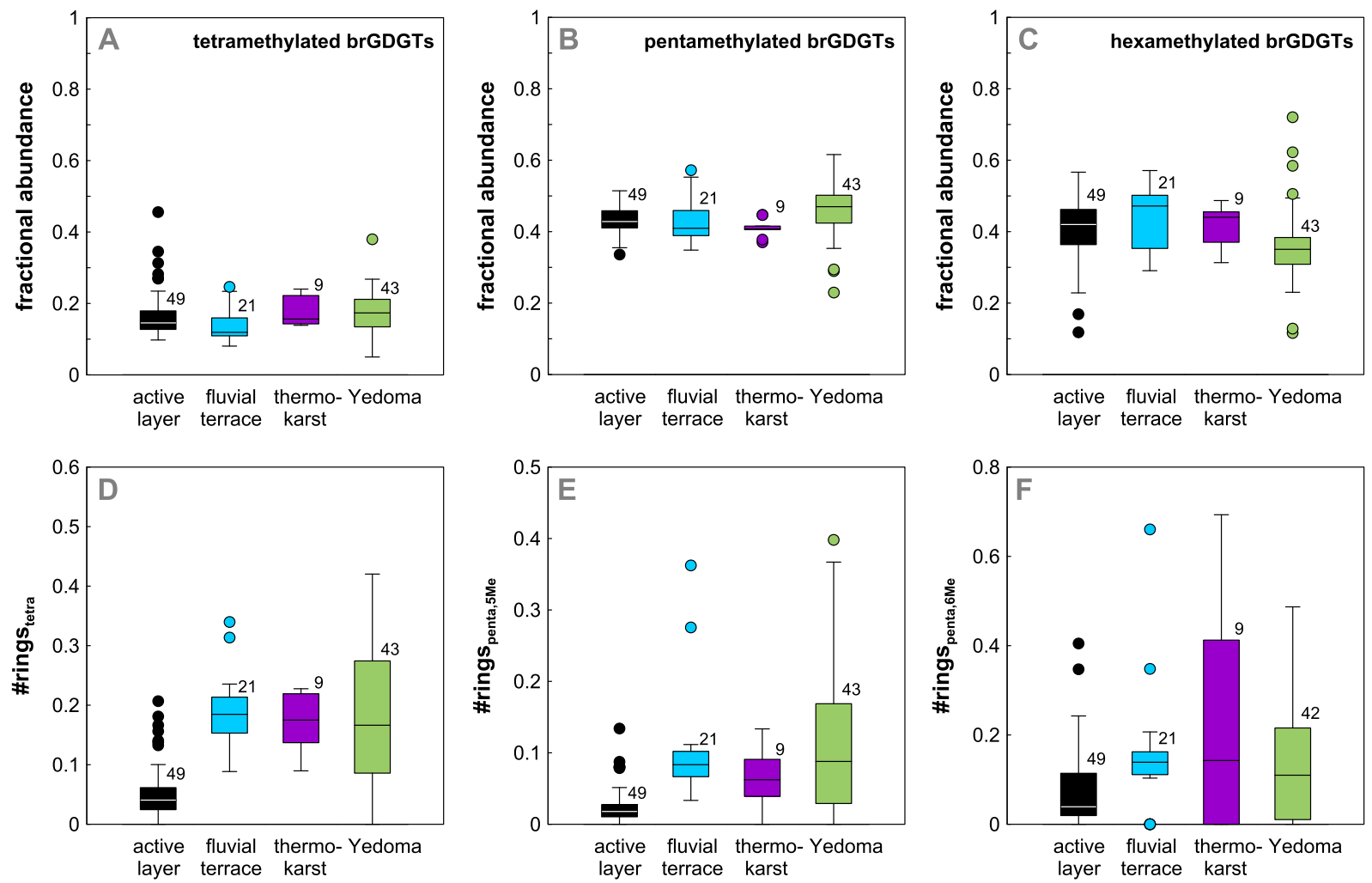

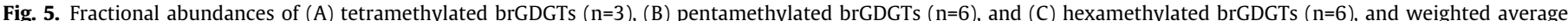

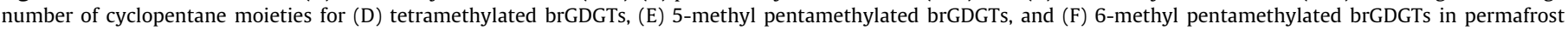
deposits of Northern Siberia. 


\subsection{GDGT diversity and environmental controls}

\subsubsection{IsoGDGTs}

While crenarchaeol and its isomer are only produced by ammonia oxidizing Thaumarchaeota, the other isoGDGTs (GDGT-0, GDGT-1, GDGT-2, and GDGT-3) are also synthesized by other archaea, including methanogenic and methanotrophic Euryarchaeota (Blaga et al., 2008; Weijers et al., 2011). These sources are particularly likely in permafrost deposits, which have been shown to harbor a suite of methanogenic and methanotrophic microbes (Jansson and Taş, 2014). Archaeal genomic data from permafrost areas are scarce, but 16S rRNA data from methane-rich permafrost deposits of the Kolyma River floodplain show that methanogenic Euryarchaeota dominate (57-93\%) the archaeal community (Shcherbakova et al., 2016). Accordingly, we expect that GDGT-0, GDGT-1, GDGT-2, and GDGT-3 in the investigated permafrost deposits are influenced by euryarchaeal contributions. The MI confirms that the majority of the investigated samples are indeed significantly influenced by methane (Fig. 4C) with mean values of $0.6 \pm 0.3(n=45)$ in active layer soils, $0.6 \pm 0.2(n=21)$ in Holocene fluvial terrace/floodplain sediments, $0.4 \pm 0.1(n=9)$ in thermokarst sediments, and $0.4 \pm 0.2(n=43)$ in Yedoma. Moreover, mean GDGT-0/crenarchaeol ratios are $\geq 2$ in all deposit types and particularly in active layer soils (Fig. $4 \mathrm{~A}$ ), implying the presence of methanogenic Euryarchaeota (Blaga et al., 2008). This agrees well with the detection of archaeol in the Bol'shoy Lyakhovsky Island L14 cores by Stapel et al. (2018) and archaeol in a drill core from Kurungnakh Island investigated by Bischoff et al. (2013). Additionally, mean GDGT-2/crenarchaeol ratios are $\geq 0.2$ in active layer soils, Holocene fluvial terrace/floodplain sediments, and Yedoma (Fig. 4B), indicating the presence of methanotrophic Euryarchaeota in these deposit types (Weijers et al., 2011). While most thermokarst sediments have GDGT-2/crenarchaeol ratios $\leq 0.2$, a few samples (Table S2) have GDGT-2/crenarchaeol ratios $\geq 0.2$ showing that methanotrophs are also present in thermokarst sediments. We observe a strong correlation between GDGT-2 and GDGT-3 $\left(\mathrm{r}^{2}=0.96 ; \mathrm{n}=129\right)$ as well as between GDGT-0 and GDGT-1 $\left(r^{2}=0.69 ; n=129\right)$. This indicates that GDGT-3 and GDGT-1 are likely also of methanotrophic and methanogenic euryarchaeal origin, respectively. Surprisingly, we also observe particularly strong correlations between crenarchaeol and GDGT-2 $\left(r^{2}=0.93 ; n=129\right)$ and crenarchaeol and GDGT-3 $\left(r^{2}=0.96\right.$; $\mathrm{n}=129$ ). Since we consider it unlikely that both GDGT-2 and GDGT-3 in permafrost are to a significant extent sourced from Thaumarchaeota, this may indicate that methanotrophic euryarchaeal GDGT-2 and GDGT-3, as well as thaumarchaeal crenarchaeol abundances, are determined by the same environmental parameters. However, PCA $_{\text {iso }}$ (Fig. 6) reveals that any of the isoGDGT fractional abundances are not, or are only weakly, correlated with the investigated physicochemical parameters (\%TOC, \% TN or soil pH). Stapel et al. (2018) investigated additional parameters in the L14 cores from Bol'shoy Lyakhovsky Island, including free and bound acetate and formate concentrations, but none of these substrates show a correlation with the investigated isoGDGT (GDGT-0, GDGT-1, GDGT-2, and crenarchaeol) concentrations $\left(r^{2}<0.1\right)$. Accordingly, additional independent data are required to determine the environmental controls on isoGDGT abundances in permafrost deposits.

4.1.1.1. Thaumarchaeal GDGTs. Thaumarchaeota are important ammonia oxidizers in soils, which dominate over ammonium oxidizing bacteria in low pH $(<5.5)$ and low ammonia soils (Hong and Cho, 2015; Leininger et al., 2006; Prosser and Nicol, 2012; Verhamme et al., 2011). Nicol et al. (2008) showed that soil acidity is the best predictor of thaumarchaeal abundances in soil, while Bates et al. (2011) concluded that thaumarchaeal abundances are

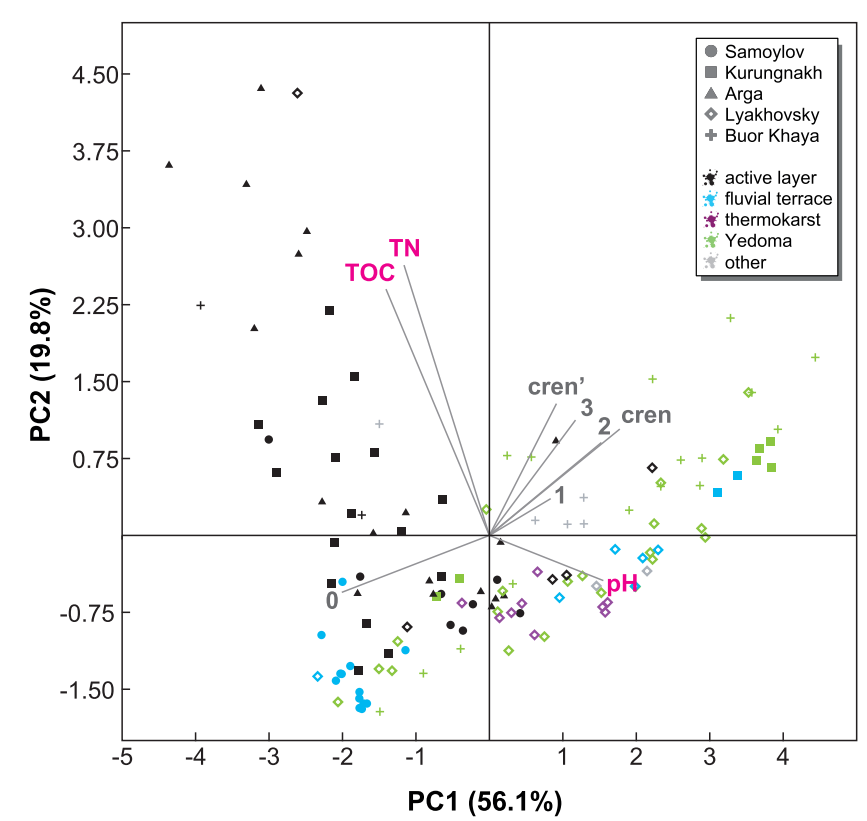

Fig. 6. $\mathrm{PCA}_{\text {iso }}$ scatter plot based on physicochemical parameters and fractional isoGDGT abundances in permafrost deposits of Northern Siberia. PC1 and PC2 explain $75.3 \%$ of the data variance. Biplot annotations denote isoGDGT structures (grey; Appendix A) and physicochemical parameters (magenta).

most closely related to soil $\mathrm{C} / \mathrm{N}$ ratios and Hong et al. (2015) found a negative correlation between thaumarchaeal abundances and $\mathrm{OM}$ and water content. Regression coefficients for crenarchaeol abundances and physicochemical parameters including \%TOC (Fig. 7A), \%TN (Fig. 7B), C/N ratios (Fig. 7C), and pH (Fig. 7D), respectively, reveal that in the investigated North Siberian permafrost samples no obvious relationships between these physicochemical parameters and thaumarchaeal abundances exist. If anything, we observe a weak positive relationship between soil $\mathrm{pH}$ and crenarchaeol (Fig. 7D). This may indicate that thaumarchaeal communities in our permafrost samples differ from those in other environments, such as temperate soils. This is likely driven by the origin of the permafrost deposit types, including Yedoma and thermokarst sediments or fluvial terrace/floodplain sediments, which seem to be characterized by higher crenarchaeol concentrations and lower \%TOC (Fig. 7A). Globally, 16S rRNA sequences suggest that group I.1b and I.1c Thaumarchaeota dominate in soils (Auguet et al., 2009) while group I.1a Thaumarchaeota represent only a minority of sequences. This also seems to be confirmed by available permafrost genetic data (Gittel et al., 2014; Shcherbakova et al., 2016; Tripathi et al., 2018; Wilhelm et al., 2011). 16S rRNA clones in permafrost deposits of the Kolyma River floodplain show that besides the dominant methanogenic Euryarchaeota, $7-43 \%$ of the gene sequences represent Thaumarchaeota, Woesearchaeota, and Bathyarchaeota (Shcherbakova et al., 2016). Thaumarchaeal gene sequences belonged to the group 1.2 Thaumarchaeota (C3) and group I.1b Thaumarchaeota (Soil Crenarchaeota Group). The I.1b Thaumarchaeota were most closely related to the I.1b Nitrososphaera genus (Shcherbakova et al., 2016) of which strain JG1 and N. viennensis, as well as the thermophilic N. gargensis, have been shown to produce crenarchaeol (Pitcher et al., 2010; Sinninghe Damsté et al., 2012; Stieglmeier et al., 2014). Similarly, Gittel et al. (2014) found 16S rRNA sequences belonging to the Nitrososphaerales in permafrost soils in the upper Kolyma River area. Whether the 16S rRNA data from the Kolyma River are an analogue for our Siberian permafrost samples is uncertain. Besides the potential of PCR amplification of DNA from non-viable cells, the spatial heterogeneity might be 

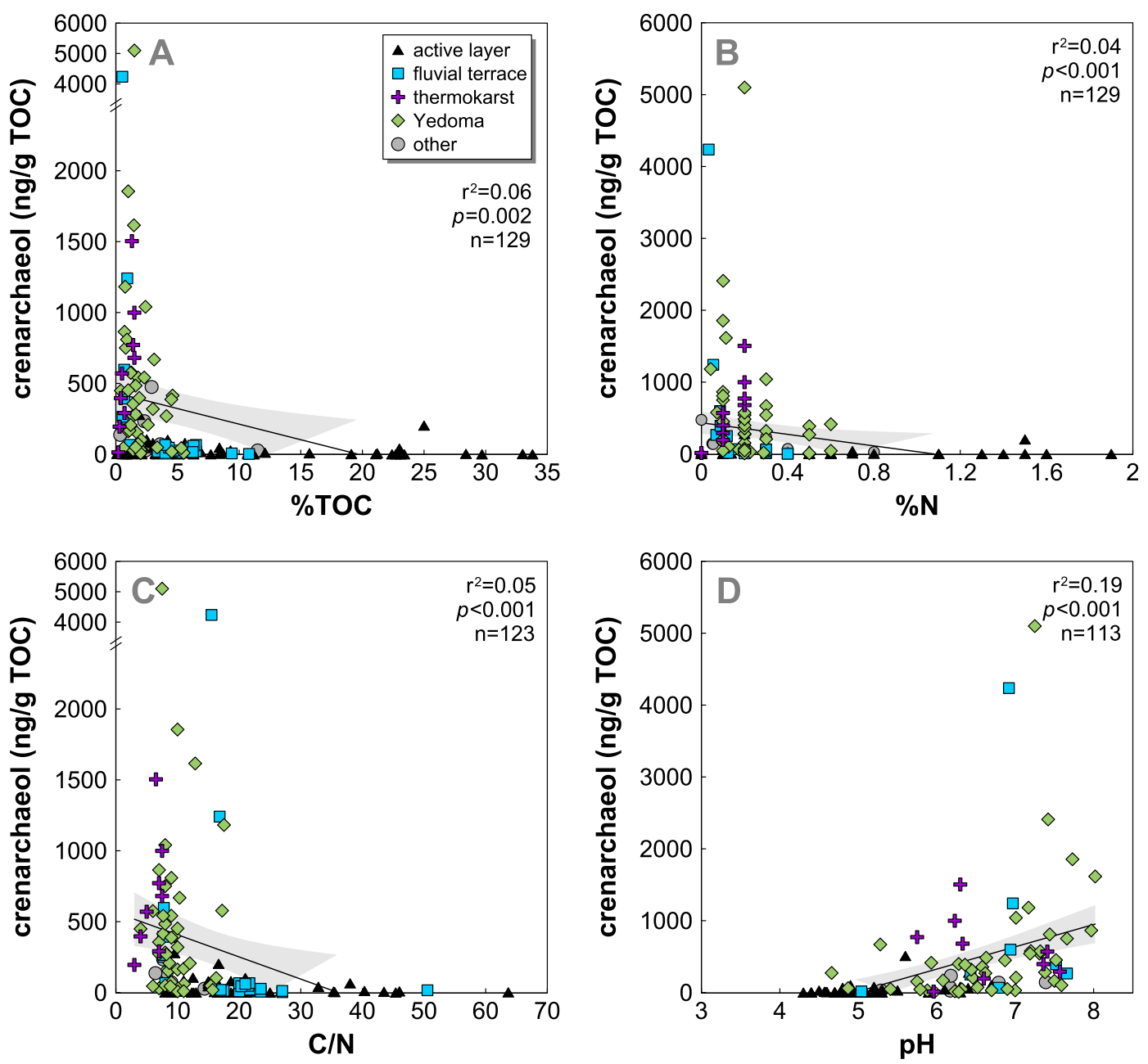

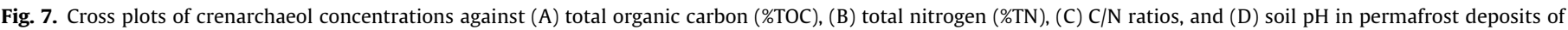
Northern Siberia. Linear fit shown with 95\% confidence interval (grey shaded area).

significant. Alaskan permafrost soils investigated by Tripathi et al. (2018) revealed a large spatial diversity, with a dominance of either group I.1b Thaumarchaeota, Euryarchaeota, or group I.1c Thaumarchaeota (formerly "Finnish Forest Soil Archaea") in permafrost soils within a ca. $300 \mathrm{~km}$ radius. The latter subgroup seems to dominate in boreal settings, but have thus far not been shown to be ammonia oxidizers and it is unknown whether they synthesize crenarchaeol (Bomberg, 2016; Isoda et al., 2017; Weber et al., 2015). Thus, while we cannot determine whether group I.1c Thaumarchaeota are reflected by crenarchaeol concentrations, our data might distinguish group I.1a and group I.1b Thaumarchaeota. Sinninghe Damsté et al. (2012) suggested that the relative abundance of the crenarchaeol isomer (cren') in the total crenarchaeol (cren) pool, i.e., the cren'/(cren + cren') ratio, differs between group I.1a and I.1b soil Thaumarchaeota. In general, cren'/(cren + cren') ratios in our permafrost deposits are below 0.1 - indicating that crenarchaeol and its isomer probably derive from group I.1a Thaumarchaeota, irrespective of deposit type (Sinninghe Damsté et al., 2012). Only six active layer soil samples from Kurungnakh and Arga Island (particularly profile AG-0103) show significantly higher cren'/(cren + cren') ratios (0.12-0.34) suggesting group I.1b Thaumarchaeota contribute significantly to the crenarchaeol pool in these soils. Thus, either North Siberian permafrost soils contain rather unusual thaumarchaeal communities or cren'/(cren + cren') ratios do not mirror in situ thaumarchaeal communities. Independent genomic data will be required to confirm the thaumarchaeal subgroup present in our samples.

\subsubsection{BrGDGTs}

The ternary plot of the relative abundance of bacterial tetra-, penta-, and hexamethylated brGDGTs (Fig. 8) shows that the Siberian permafrost deposits follow the trend described by the global soil and peat data sets. Generally, our permafrost samples are dominated by pentamethylated (mean $43.6 \pm 5.7 \%$; $n=129$ ) and hexamethylated (mean $39.5 \pm 10.0 \% ; \mathrm{n}=129$ ) brGDGTs while tetramethylated brGDGTs average $16.8 \pm 6.1 \%(n=129)$. This distribution agrees well with the composition observed in the Svalbard soils in the global data set and the Greenland soils investigated by Colcord et al. (2015) and is consistent with a temperature control on the methylation of brGDGTs (De Jonge et al., 2014; Peterse et al., 2009; Weijers et al., 2007). The degree of methylation is relatively homogenous among deposit types (Fig. 5A-C), while they are characterized by different weighted average number of cyclopentane moieties (\#rings; Fig. 5D-F). This is particularly obvious for tetra- and 5-methyl pentamethylated brGDGTs which correlate positively with each other $\left(r^{2}=0.67\right.$; $\mathrm{n}=129$ ). Active layer soils show the lowest \#ringstetra, \#rings $_{\text {penta,5Me, and \#rings }}$ penta,6Me values while Yedoma has the highest \#rings tetra $_{\text {, }}$ \#rings penta,5Me, and \#rings $_{\text {penta,6Me values. This }}$ is consistent with global observations showing that the number 


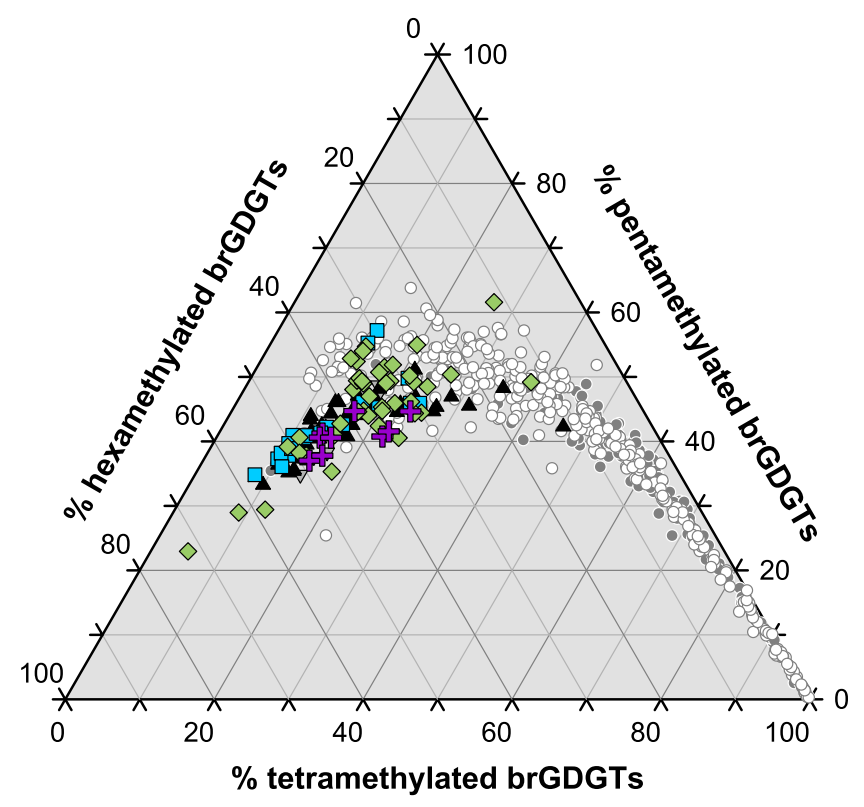

$\Delta$ active layer $\diamond$ Yedoma $\odot$ global soil database
$\square$ fluvial terrace $\nabla$ other $\bullet$ global peat database
$\downarrow$ thermokarst

Fig. 8. Ternary plot of the relative abundance of tetra-, penta-, and hexamethylated brGDGTs in permafrost deposits of Northern Siberia $(n=129)$ superimposed on the global soil data set of De Jonge et al. (2014) and the global peat data set of Naafs et al. (2017).

of cyclopentane moieties increases with $\mathrm{pH}$, which is highest in Yedoma and lowest in active layer soils (Fig. 2C). Likewise, the abundance of 6-methyl brGDGTs (degree of isomerization; IR $_{6 \mathrm{Me}}$ ) increases with increasing $\mathrm{pH}$ (Fig. 9)- similar to observations in the global soil data set and in global peats (De Jonge et al., 2014; Naafs et al., 2017). However, the correlation in the permafrost deposits is weak $\left(r^{2}=0.18 ; n=113\right)$ since $I_{6 M e}$ values of both fluvial terrace/floodplain sediments and thermokarst sediments do not change significantly with increasing $\mathrm{pH}$. It remains to be investigated whether the degree of cyclization and degree of isomerization are physiological responses of specific (acido)bacterial species to soil $\mathrm{pH}$, or instead reflect different bacterial species assemblages with different physiological traits. Sinninghe Damsté et al. (2018) recently demonstrated that the distribution of 6-methyl iso-diabolic acid (the potential building block for 6-methyl brGDGTs) in cultured acidobacterial strains differs between acidobacterial subdivisions. For example, strains belonging to subdivisions 1 and 3 , which often accumulate in acidic soils, were shown to produce low amounts of 6-methyl iso-diabolic acid, while strains belonging to subdivision 6 , which occur in high $\mathrm{pH}$ soils, have high 6-methyl iso-diabolic acid contents (Sinninghe Damsté et al., 2018). As discussed above, these authors highlighted that the search for the bacterial source organisms of brGDGTs should be extended to bacterial phyla other than Acidobacteria (Sinninghe Damsté et al., 2018). Nonetheless, the Acidobacteria have been shown to be an important phylum in permafrost deposits throughout the Arctic, where the occurrence of Acidobacteria seems to be predominantly linked to $\mathrm{pH}$ (e.g. Ganzert et al., 2014; Gittel et al., 2014; Kim et al., 2014; Wilhelm et al., 2011; Männistö et al., 2007). Significant acidobacterial 16S rRNA gene sequence abundances were also detected in permafrost deposits in the Kolyma Indigirka lowlands (16\%; Zhou et al., 1997) and Samoylov Island active layer soils (ca. 10\%; Liebner et al., 2008), while a $28 \mathrm{~m}$ deep sample obtained from Bykovsky Peninsula,

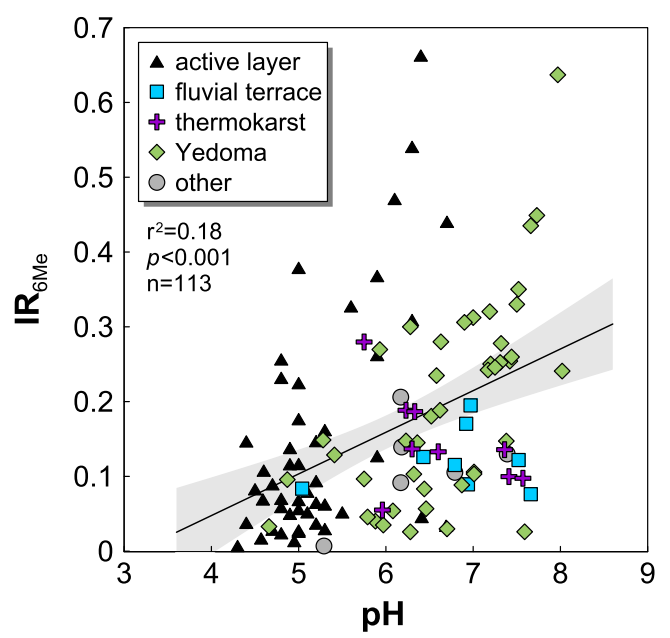

Fig. 9. Cross plot of the degree of isomerization ( $\mathrm{IR}_{6 \mathrm{ME}}$ ) against soil $\mathrm{pH}$ in permafrost deposits of Northern Siberia. Linear fit shown with 95\% confidence interval (grey shaded area).

south of the Lena Delta, revealed only minor contributions (1\%) from Acidobacteria (Hinsa-Leasure et al., 2010). We observe the highest total brGDGT concentrations (Fig. 3B) in the samples with the lowest $\mathrm{pH}$ (active layer soils; Fig. 2C), which may provide circumstantial evidence for an acidobacterial origin of brGDGTs. Additional correlations between brGDGT fractional abundances and the investigated physicochemical parameters are revealed by PCA $_{\text {br }}$ (Fig. 10). The physicochemical parameters separate on PC1 and show a negative correlation of \%TOC and \%TN with $\mathrm{pH}$. BrGDGT-IIIa correlates positively with \%TOC and \%TN, although PC3 (9.9\% of the variance, not shown) separates a distinct cluster of a few Arga Island active layer soils which are characterized by very low abundance of brGDGT-IIIa but high \%TOC. Opposite to brGDGT-IIIa, the other brGDGTs without cyclopentane moieties (IIIa', IIa, IIa', and Ia) do not seem to correlate with any of the

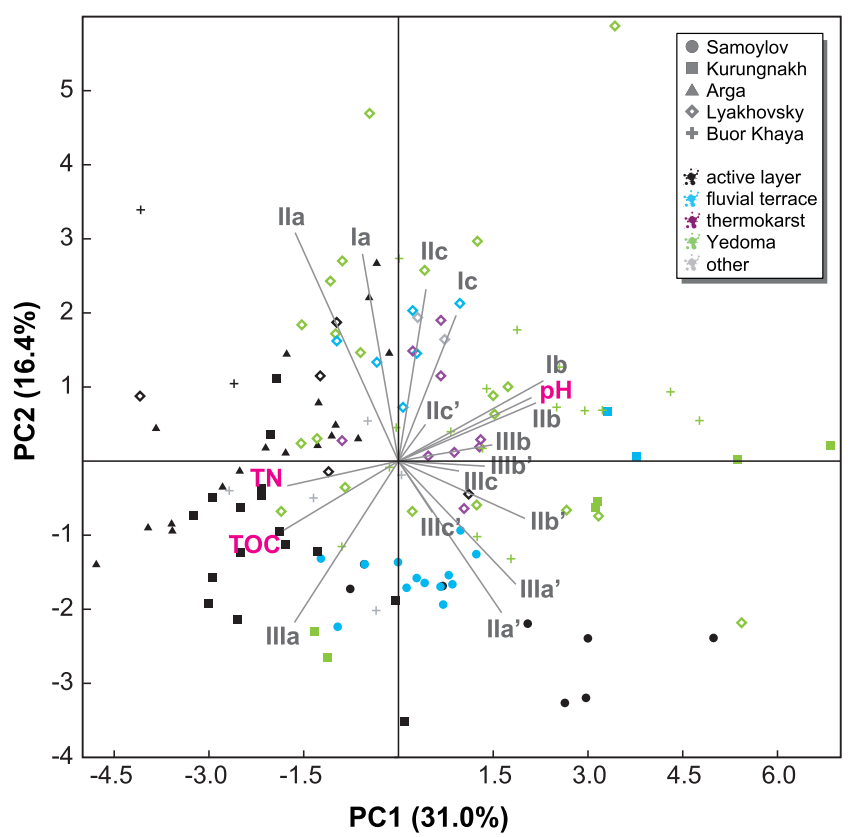

Fig. 10. $P C A_{b r}$ scatter plot based on elemental data and fractional brGDGT abundances in permafrost deposits of Northern Siberia. PC1 and PC2 explain $50.5 \%$ of the data variance. Biplot annotations denote brGDGT structures (grey; Appendix A) and physicochemical parameters (magenta). 
investigated physicochemical parameters but show a distinct negative correlation between the 5-methyl (IIa and Ia) and 6-methyl (IIIa' and IIa') brGDGTs on PC2 (Fig. 10). This separation distinctly clusters permafrost samples from Bol'shoy Lyakhovsky Island (high 5-methyl brGDGT abundances) apart from Samoylov active layer soils and fluvial terrace/floodplain sediments (high 6-methyl brGDGT abundances). This likely reflects different bacterial populations in the respective deposit types and may be caused in part by their different origin. The $\mathrm{PCA}_{\mathrm{br}}$ also shows the strongest positive correlation with $\mathrm{pH}$ (and negative correlation with \%TOC and \%TN) for brGDGT-Ib and brGDGT-IIb as well as brGDGTs IIIb and IIIb'. Abundances of cyclized hexamethylated brGDGTs IIIc, IIIc', and pentamethylated brGDGT-IIc' show no or weak correlations with any physicochemical parameter- since they only occur in low concentrations in a subset of the investigated samples. The correlations observed between brGDGTs and $\mathrm{pH}$ indicate that brGDGT abundances can be used to determine a permafrostspecific $\mathrm{pH}$ transfer function irrespective of whether the observed changes are caused by physiological responses of specific (acido) bacterial species or different bacterial species assemblages.

4.1.2.1. Permafrost-specific soil $p H$ calibration. The global soil data set shows a positive correlation between the relative abundance of brGDGTs with cyclopentane moieties and soil $\mathrm{pH}$, while brGDGTs without cyclopentane moieties correlate negatively with soil pH (De Jonge et al., 2014). Moreover, upon improved chromatographic separation, De Jonge et al. (2014) showed that the relative abundance of 6-methyl brGDGTs correlates positively with soil $\mathrm{pH}$. Overall, this pattern is mirrored in our permafrost data set (Fig. 11). However, the observed correlation coefficients are lower and the trends observed for specific brGDGT abundances differ from the global data set. Most obviously, we observe no corre- lation of brGDGT-Ia and $\mathrm{pH}$, which show the strongest negative correlation in the global soil data set. In contrast, as revealed by the PCA we observe the strongest negative correlation between $\mathrm{pH}$ and the relative abundance of brGDGT-IIIa (Figs. 10 and 11), which do not correlate in the global soil data set. Accordingly, inferring soil $\mathrm{pH}$ using a multiple regression transfer function based on the relative abundance of brGDGTs in the global soil data set such as $\mathrm{pH}_{\mathrm{mr}}(2014)$ results in very weak correlation $\left(\mathrm{r}^{2}=0.12\right)$ with the measured soil pH (Fig. 12C). Using CBT' as defined by De Jonge et al. (2014), the correlation improves slightly $\left(r^{2}=0.23\right.$; Fig. 12A). This likely results from the lack of correlation between 6-methyl brGDGT relative abundance and soil $\mathrm{pH}$ in our permafrost data set (Fig. 11). This is reflected in the weak correlation between $I_{6 \mathrm{Me}}$ and soil $\mathrm{pH}$ (Fig. 9) and may result from high water contents of permafrost (Dang et al., 2016). Accordingly, excluding 6-methyl brGDGTs as defined by the $\mathrm{CBT}_{5 \mathrm{Me}}$ index of De Jonge et al. (2014), strongly improves correlation with measured soil $\mathrm{pH}$ values $\left(\mathrm{r}^{2}=0.52\right.$; Fig. $\left.12 \mathrm{~B}\right)$.

In order to determine a permafrost-specific $\mathrm{CBT}_{\mathrm{PF}}$ index yielding the strongest possible correlation with soil $\mathrm{pH}$, we used combinatorial analysis computed using Wolfram Mathematica software. We excluded those brGDGTs (IIIc, IIIb', IIIc', IIc', and IIIc) that occurred in $\leq 50 \%$ of the samples. The strongest correlation coefficient was found for $\mathrm{CBT}_{\mathrm{PF}}$ (Fig. 12D,E) defined as:

$$
C B T_{P F}=\log \left(\frac{I c}{I I a}\right)
$$

and $\mathrm{pH}$ can be described as a function of $\mathrm{CBT}_{\mathrm{PF}}$ following:

$$
\begin{gathered}
p H_{P F}=1.6153 \times C B T_{P F}+9.8909\left(\mathrm{r}^{2}=0.63,\right. \\
p<0.001 ; \mathrm{RMSE}=0.057 ; \mathrm{n}=83)
\end{gathered}
$$
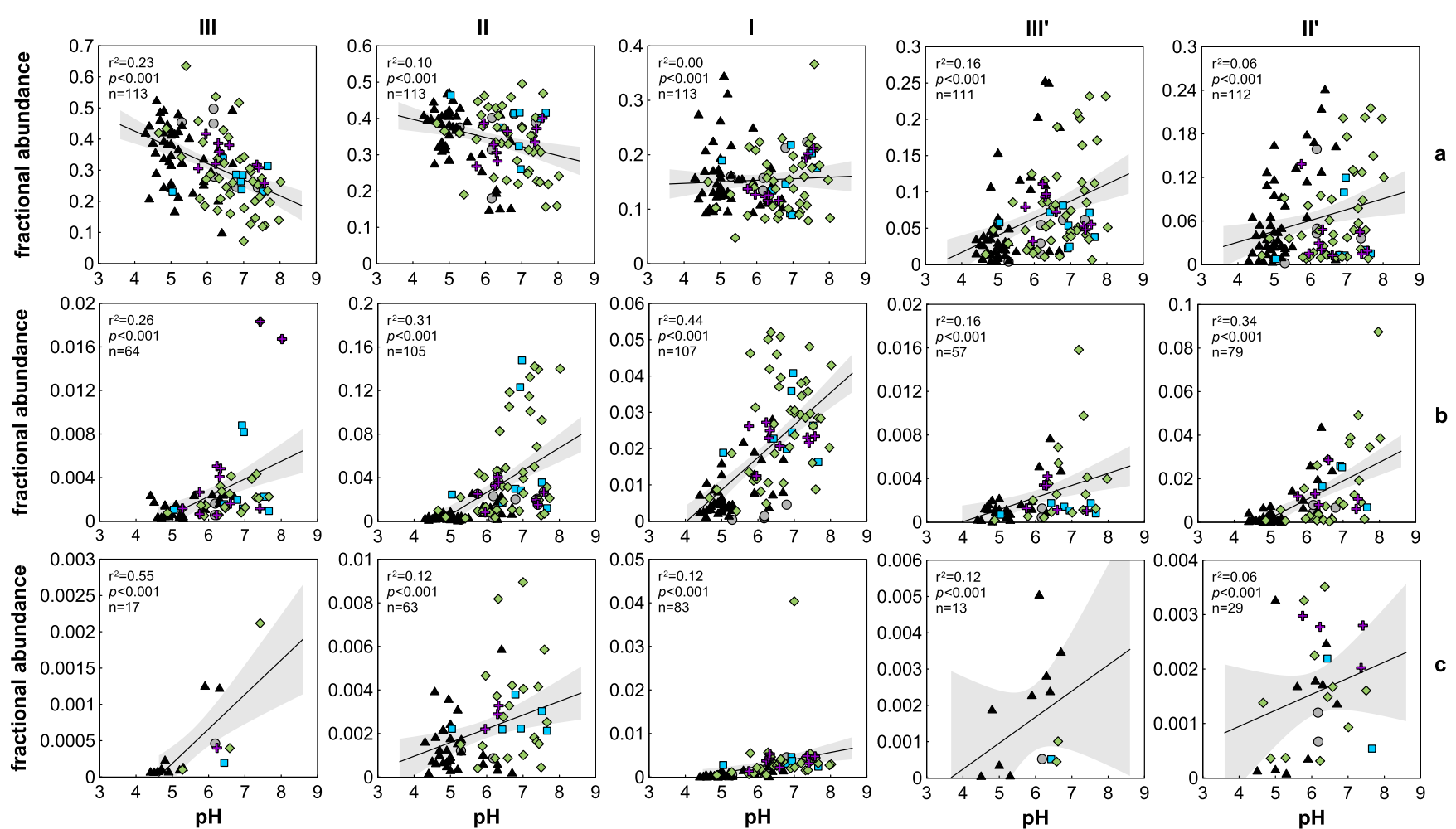

$\Delta$ active layer $\square$ fluvial terrace $\quad+$ thermokarst $\diamond$ Yedoma $\quad$ other

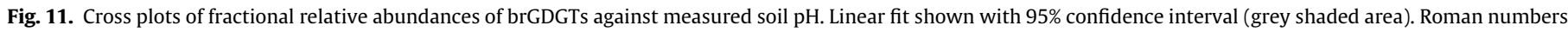
and letters denote brGDGT structures (see Appendix A). 

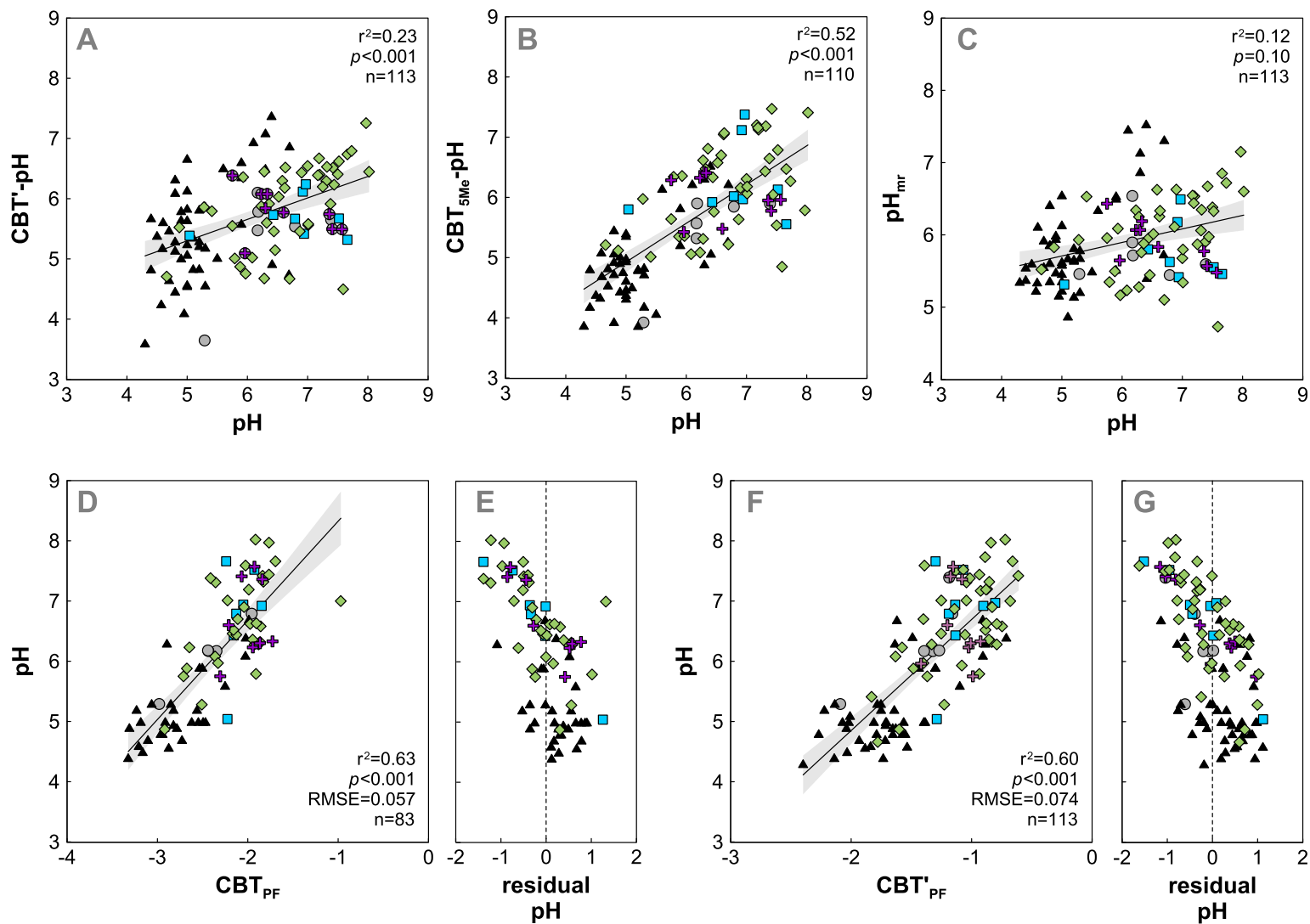

$\Delta$ active layer $\square$ fluvial terrace $\$$ thermokarst $\diamond$ Yedoma $\bigcirc$ other

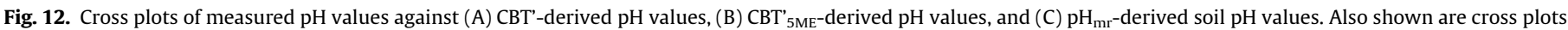

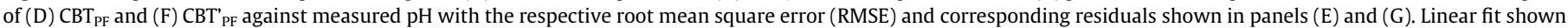
with $95 \%$ confidence interval (grey shaded area).

However, since brGDGT-Ic was not detected in $23 \%$ of the investigated samples, thus, potentially hampering the use of $\mathrm{CBT}_{\mathrm{PF}}$ in other permafrost samples, we opted for the strongest correlation between $\mathrm{CBT}_{\mathrm{PF}}$ and soil $\mathrm{pH}$ including $>95 \%$ of the investigated samples ( $\mathrm{n}=125)$, defining $\mathrm{CBT}_{\mathrm{PF}}$ as:

$C B T^{\prime}{ }_{P F}=\log \left(\frac{I b+I c+I I c}{I I a}\right)$

with $\mathrm{pH}$ modeled as a function of $\mathrm{CBT}_{\mathrm{PF}}$ (Fig. 12F, G) defined as:

$$
\begin{gathered}
p H_{P F}^{\prime}=1.8451 \times C B T_{P F}^{\prime}+8.5396\left(r^{2}=0.60,\right. \\
p<0.001 ; \text { RMSE }=0.074 ; \mathrm{n}=109)
\end{gathered}
$$

The residual pH (Fig. 12G) is similar to the residual pH observed in the global soil data set of De Jonge et al. (2014) and smaller than the residual pH observed in the peat data set of Naafs et al. (2017). The residuals show a slight bias towards soil $\mathrm{pH}$ underestimation at high $\mathrm{pH}$ and overestimation at low $\mathrm{pH}$; a pattern also evident in the global soil data set of De Jonge et al. (2014). However, the residuals are not strongly heteroscedastic, suggesting that they are random enough to apply a linear model.

Similar to that observed for the peat data set of Naafs et al. (2017), the correlation between $\mathrm{CBT}^{\prime}{ }_{\mathrm{PF}}$ and soil $\mathrm{pH}$ is weaker than the correlation between $\mathrm{CBT}^{\prime}$ and soil $\mathrm{pH}\left(\mathrm{r}^{2}=0.85\right)$ observed for the global soil data set. Naafs et al. (2017) attributed the strong correlation between $\mathrm{CBT}^{\prime}$ and soil $\mathrm{pH}$ in the global data set to amplification of the $\mathrm{pH}$ effect on brGDGT cyclization by the soil water content effect (Dang et al., 2016), which is absent in water saturated peats. This most likely also applies to permafrost depos- its, which have high (frozen) water contents. In addition to the soil water effect, we cannot exclude that brGDGT cyclization in our samples is in part also influenced by other parameters, such as MAT. As shown in Fig. 12, the most pronounced soil pH differences exist between active layer soils and Yedoma, i.e., between annually thawing and permanently frozen deposits. If the influence of temperature and $\mathrm{pH}$ are unidirectional for specific brGDGTs, e.g., observed for brGDGT-Ia in the global soil data set by (De Jonge et al., 2014), CBT may be biased by MAT and MBT by soil pH. Thus, care should be taken when applying the $\mathrm{CBT}^{\prime}{ }_{\mathrm{PF}}$ proxy in high latitude locations with different production environments.

\subsection{GDGT distributions in the different deposit types and implications for GDGT-based proxies in marine sediments}

Several studies used GDGT distributions, i.e., BIT indices, in coastal East Siberian Arctic Shelf sediments to determine the supply of terrestrial permafrost-derived OC to these settings (Dog rul Selver et al., 2015; Ho et al., 2014; Sparkes et al., 2015; De Jonge et al., 2015; van Dongen et al., 2008). While De Jonge et al. (2015) found a good agreement of BIT index values with bulk sedimentary $\delta^{13} \mathrm{C}$ and $\mathrm{C} / \mathrm{N}$ ratios in the Kara Sea, Doğrul Selver et al. (2015) and Sparkes et al. (2015) found different trends for BIT index values (exponential decrease) and other proxies including $R_{\text {soil }}$ and bulk sedimentary $\delta^{13} \mathrm{C}$ (linear decrease) across the shelf in both the Laptev Sea and the East Siberian Sea. Doğrul Selver et al. (2015) suggested that this may reflect OM contributions of different deposit types such as permafrost soils and Yedoma supplied via different delivery modes, i.e., fluvial runoff and coastal 
erosion. Yet, the constraints on GDGT distributions in catchment deposits were limited to a few Yedoma samples. Our data set allows us to determine more comprehensively whether specific GDGT distributions may be used to fingerprint the investigated deposit types and whether erosion of different deposit types may have implications for the signals recorded in marine (or other aquatic) sediments.

Doğrul Selver et al. (2015) and Peterse et al. (2014) found that Yedoma is characterized by low brGDGT concentrations ( $\sim 3-$ $10 \mu \mathrm{g} / \mathrm{g}$ TOC) and Doğrul Selver et al. (2015) concluded that high brGDGT concentrations in coastal sediments thus preclude substantial contributions from Yedoma via coastal erosion. However, Peterse et al. (2014) investigated only one, and Doğrul Selver et al. (2015) only three, Yedoma samples. On average, we observe higher total brGDGT concentrations in Yedoma samples $(37.6 \pm 72.5 \mu \mathrm{g} / \mathrm{g}$ TOC; $\mathrm{n}=32)$ than previously reported, and maximum concentrations are as high as $419.2 \mu \mathrm{g} / \mathrm{g}$ TOC similar to the maximum concentrations detected in the other deposit types (Fig. 3B). Overall, brGDGT concentrations in fluvial terrace/floodplain sediments, thermokarst sediments, and Yedoma do not differ significantly. While active layer soils indeed have higher brGDGT concentrations, the difference is less than one order of magnitude for the majority of the data (Fig. 3B). We also observe relatively similar total isoGDGT concentrations across deposit types (Fig. 3A). Thus, the different deposit types cannot be easily identified based on GDGT concentrations and conclusions as to which deposit type and/or delivery mechanism contributes GDGTs to coastal sediments should not be based on absolute GDGT abundances alone.

In contrast, the relative contributions of specific GDGTs may be a better predictor of deposit type. Peterse et al. (2014) first noted that Yedoma from the Kolyma catchment was characterized by high relative crenarchaeol abundances. High relative abundances of crenarchaeol in Kolyma and Indigirka catchment Yedoma were confirmed by Bischoff et al. (2016), but these authors found lower relative crenarchaeol abundances in Yedoma from the Lena Delta. The Yedoma samples in our data set indeed have high crenarchaeol abundances relative to total GDGTs (Fig. 3F) and relative to isoGDGTs (Fig. 4D) in particular (mean $30.5 \pm 19.0 \%$; $n=43$ ). Accordingly, Yedoma has lower BIT index values in comparison to the other deposit types (Fig. $4 \mathrm{E}$ ). The $\mathrm{PCA}_{\text {iso }}$ revealed a negative correlation of crenarchaeol with isoGDGT-0 (Fig. 6), thus, the GDGT-0/(cren + GDGT-0) ratio (Fig. 4F) may be a useful indicator to distinguish different deposit types. The GDGT-0/(cren + GDGT0 ) ratio separates active layer soils and Yedoma well from each other and reasonably well from fluvial terrace/floodplain sediments and thermokarst sediments. The latter two deposit types show rather similar overall GDGT distributions (Fig. 3D,E) and may, thus, not be distinguishable- irrespective of which ratio is used. Based on the difference in soil $\mathrm{pH}$ of the different deposit types, $\mathrm{CBT}_{\mathrm{PF}}$ provides an additional means to distinguish the different deposit types, particularly active layer soils and Yedoma (Fig. 12F). Using crenarchaeol relative abundances, GDGT-0/ (crenarchaeol + GDGT-0) ratios, and CBT' ${ }_{\mathrm{PF}}$ may, thus, aid in distinguishing the different deposit types. Nonetheless, it should be noted that the variance of GDGT distributions and ratios within each deposit type is quite large, both between sites and at a given site. For example, total brGDGT concentrations in all Yedoma samples average $41.2 \mu \mathrm{g} / \mathrm{g}$ TOC with a significant standard deviation of $96.2 \mu \mathrm{g} / \mathrm{g}$ TOC. Yedoma total brGDGT concentrations also differ between sites, ranging from means of $16.8 \pm 14.2 \mu \mathrm{g} / \mathrm{g}$ TOC on the Buor Khaya Peninsula (BK-8) to $44.6 \pm 118.5 \mu \mathrm{g} / \mathrm{g}$ TOC (L14-02) or $124.9 \pm 96.8 \mu \mathrm{g} / \mathrm{g}$ TOC on Bol'shoy Lyakhovsky Island (L14-05). At all sites, however, evidently high standard deviations highlight the strong heterogeneity, even at a given site. This warrants cau- tion when defining deposit type-specific endmembers and applying these endmembers to mass balance calculations. It also highlights that fingerprinting GDGT assemblages based on a limited number of samples likely underestimates the natural heterogeneity and may cause misinterpretation.

While not all deposit types have distinct GDGT fingerprints (e.g. fluvial terrace/floodplain sediments and thermokarst sediments), it is still obvious that variable contributions from different sources through time may significantly bias GDGT proxy signals in sedimentary downcore records obtained from the Siberian Arctic shelf. A decrease of BIT, for example, may be caused by a relative increase of Yedoma, or a relative decrease of active layer soil OC contributions to the exported terrestrial OC pool, respectively, rather than providing quantitative estimates of permafrost erosion. This mechanism was also invoked by De Jonge et al. (2016a) to explain a marked shift towards lower BIT indices observed in unit $2 \mathrm{~d}$ of their Kara Sea record. The authors observed both a change in brGDGT distributions and concentrations, which was not accompanied by an increase of crenarchaeol concentrations or cyclopentanecontaining brGDGTs- indicating increased marine in situ production. Similarly, physicochemical changes through time inferred using GDGT proxies such as CBT (and likely also MBT) might potentially be biased by variable contributions from the different deposit types, particularly from Yedoma and active layer soils, which have distinct $\mathrm{pH} / \mathrm{CBT}$ ranges. Again, such an effect was proposed by De Jonge et al. (2016a) to explain a pH decrease of about 0.5 units and a sharp $\mathrm{MAT}_{\text {mrs }}$ increase of ca. $8^{\circ} \mathrm{C}$ temperature in unit $2 \mathrm{~d}$ of core N9 in the Kara Sea.

In addition to the GDGT signals carried by the erosion of different deposit types, in situ production in the river and on the shelf (De Jonge et al., 2015; Peterse et al., 2014) will contribute OC carrying additional GDGT signatures, thus, further complicating the interpretation of downcore records in the Siberian Arctic Ocean. De Jonge et al. (2015) showed that suspended particulate matter (SPM) produced in situ in the Yenisei River is characterized by high fractional abundances of 6-methyl brGDGTs IIa' and IIIa'. The relative contribution of these brGDGTs is rather homogenous in our samples and their summed abundances average $11.5 \pm 8.7 \%$ although several active layer soils have summed abundances $>30 \%$ and maximum summed abundances are as high as $48.7 \%$ (SA-R, 13-18 cm), similar to that observed by De Jonge et al. (2015) in the Yenisei River SPM. Accordingly, increased 6-methyl brGDGT abundances in marine sediments may not simply indicate increased aquatic in situ production, but may also derive from permafrost in the catchment. However, the threshold value for \#rings $_{\text {tetra }}$ determined by Sinninghe Damsté (2016) to indicate significant in situ production (0.7) is not exceeded by any of the investigated deposit types in our data set. Thus, \#rings tetra should provide reliable estimates of in situ production in paleoclimatic studies. Consequently, the effect of aquatic in situ production and varying contributions from different deposit types may also offset each other. For example, if marine in situ production of brGDGTs contributes brGDGTs with low CBT values, while the terrigenous contribution of brGDGTs derived from Yedoma (high CBT values) increases, the overall CBT value may not change if the respective contributions and proxy values are equal in terms of mass balance. Accordingly, thorough and statistically meaningful investigations of the GDGT distributions in all sources contributing OC to marine sediments, including the different terrestrial deposit types in a given catchment, riverine and lacustrine suspended matter and sediments and likely even marine suspended matter, are required to estimate reliably, the effect on GDGT distributions determined in marine sediments in the Siberian Arctic. Given the large heterogeneity of circumpolar permafrost pedons and their carbon stocks (e.g., Hugelius et al, 2014), GDGT abundances likely differ 
regionally. Thus, we would advise investigation of GDGT abundances in a sufficient number of permafrost deposits from the respective catchments when studying marine sediments.

\section{Conclusions}

We investigated the GDGT assemblages in 129 Siberian permafrost samples- representing the active layer of polygonal tundra soils, fluvial terrace/floodplain sediments, Eemian and Holocene thermokarst sediments, and late Pleistocene Ice Complex (Yedoma)- in order to better understand GDGT diversity and environmental controls at high latitude. GDGT abundances were dominated by bacterial brGDGTs in all deposit types and showed distributional changes, which were correlated to physicochemical parameters, including \%TOC, \% TN, and soil $\mathrm{pH}$. The positive correlation of the degree of cyclization with soil $\mathrm{pH}$ allowed us to propose a permafrost-specific soil $\mathrm{pH}$ calibration with a root mean square error of $0.074(n=109)$. The dominance of pentamethylated and hexamethylated brGDGTs agreed well with the global soil data for the different deposit types due to high heterogeneity in any deposit type, variable contributions from these sources to the eroded/exported permafrost OC may severely alter GDGT proxies analyzed in marine or other aquatic sediments.

\section{Acknowledgements}

We thank Sarah Trojahn, Jens Hefter, and Reaz Hossain for help in the lab and Dominik Hezel for help with Mathematica computing. We are also grateful to Sebastian Zubrzycki and Pier Paul Overduin for providing the Arga Island samples and the Buor Khaya drill core, respectively. We also thank Cindy de Jonge and one anonymous reviewer for their constructive feedback.

This study was funded by the German Ministry of Education and Research (BMBF) within the framework of the joint GermanRussian CARBOPERM project [BMBF grant 03G0836].

\section{Appendix A}

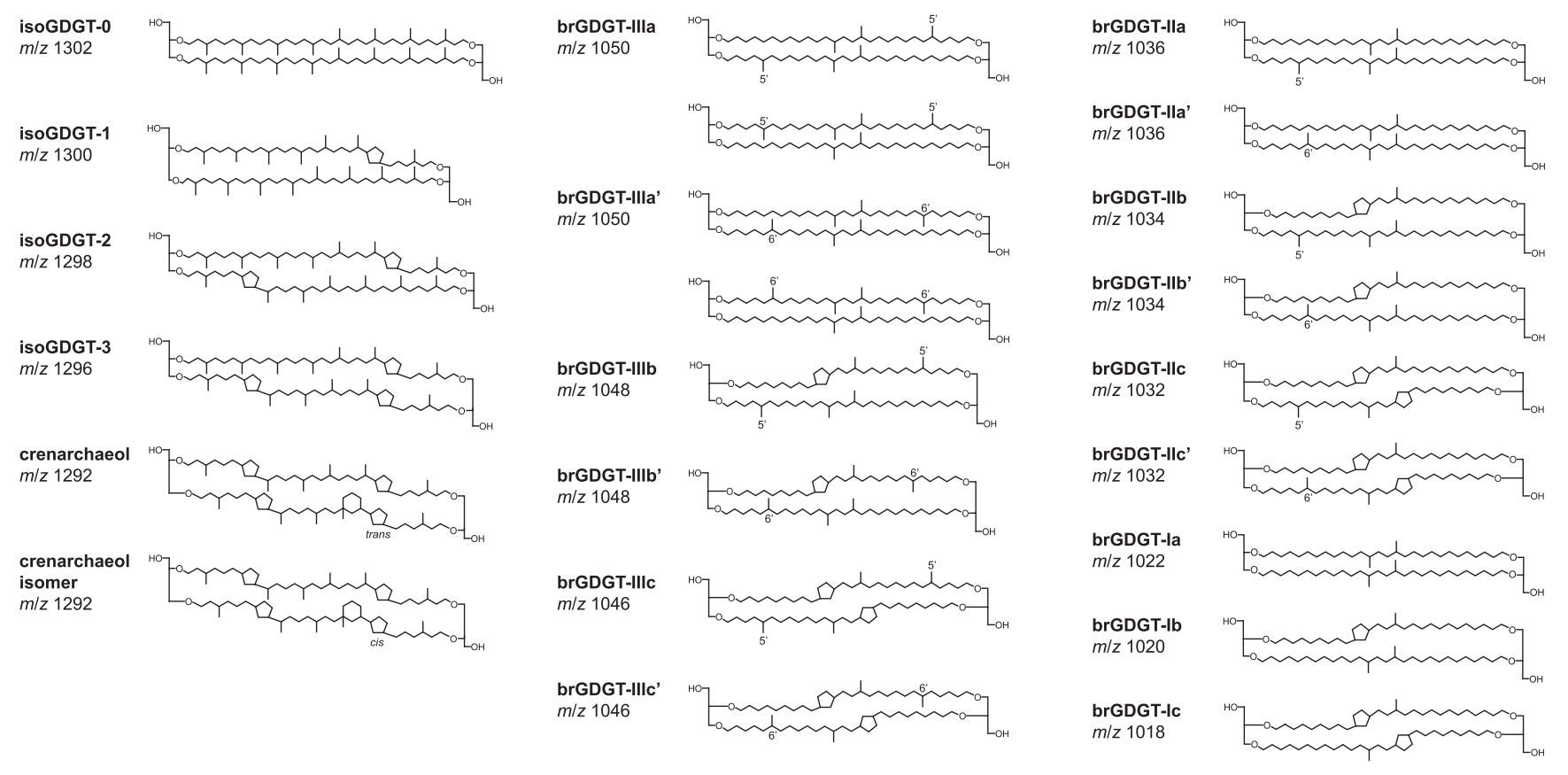

set of De Jonge et al. (2014), reflecting a low temperature adaptation. However, since most of our permafrost samples were permanently frozen and included a range of Pleistocene and Holocene deposits, we refrained from using the degree of methylation to attempt a temperature calibration.

In contrast to brGDGTs, the relative abundance of isoGDGTs was not correlated to the investigated physicochemical parameters. However, isoGDGT relative abundances differed between deposit types and, thus, provide important information when fingerprinting different deposit types. This seems to be largely driven by changes in the relative contribution of Thaumarchaeota and methanotrophic and methanogenic Euryarchaeota, i.e., crenarchaeol/isoGDGT and GDGT-0/(crenarchaeol + GDGT-0) ratios. While caution should be taken when defining GDGT endmembers

\section{Appendix B. Supplementary material}

Supplementary data to this article can be found online at https://doi.org/10.1016/j.orggeochem.2019.06.009.

\section{Associate editor-Klaas G.J. Nierop}

\section{References}

Auguet, J.-C., Barberan, A., Casamayor, E.O., 2009. Global ecological patterns in uncultured Archaea. The ISME Journal 4, 182-190.

Bates, S.T., Berg-Lyons, D., Caporaso, J.G., Walters, W.A., Knight, R., Fierer, N., 2011. Examining the global distribution of dominant archaeal populations in soil. The ISME Journal 5, 908-917. 
Bischoff, J., Mangelsdorf, K., Gattinger, A., Schloter, M., Kurchatova, A.N., Herzschuh, U., Wagner, D., 2013. Response of methanogenic archaea to Late Pleistocene and Holocene climate changes in the Siberian Arctic. Global Biogeochemical Cycles 27, 305-317.

Bischoff, J., Sparkes, R.B., Doğrul Selver, A., Spencer, R.G.M., Gustafsson, Ö., Semiletov, I.P., Dudarev, O.V., Wagner, D., Rivkina, E., van Dongen, B.E., Talbot, H.M., 2016. Source, transport and fate of soil organic matter inferred from microbial biomarker lipids on the East Siberian Arctic Shelf. Biogeosciences 13, 4899-4914.

Blaga, C.I., Reichart, G.-J., Heiri, O., Sinninghe Damsté, J.S., 2008. Tetraether membrane lipid distributions in water-column particulate matter and sediments: a study of 47 European lakes along a north-south transect. Journal of Paleolimnology 41, 523-540.

Bomberg, M., 2016. The elusive boreal forest thaumarchaeota. Agronomy 6, 36-39.

Colcord, D.E., Cadieux, S.B., Brassell, S.C., Castañeda, I.S., Pratt, L.M., White, J.R., 2015. Assessment of branched GDGTs as temperature proxies in sedimentary records from several small lakes in southwestern Greenland. Organic Geochemistry 82, 33-41.

Dang, X., Yang, H., Naafs, B.D.A., Pancost, R.D., Xie, S., 2016. Evidence of moisture control on the methylation of branched glycerol dialkyl glycerol tetraethers in semi-arid and arid soils. Geochimica et Cosmochimica Acta 189, 24-36.

De Jonge, C., Hopmans, E.C., Zell, C.I., Kim, J.-H., Schouten, S., Sinninghe Damsté, J.S., 2014. Occurrence and abundance of 6-methyl branched glycerol dialkyl glycerol tetraethers in soils: Implications for palaeoclimate reconstruction. Geochimica et Cosmochimica Acta 141, 97-112.

De Jonge, C., Stadnitskaia, A., Cherkashov, G., Sinninghe Damsté, J.S., 2016a. Branched glycerol dialkyl glycerol tetraethers and crenarchaeol record postglacial sea level rise and shift in source of terrigenous brGDGTs in the Kara Sea (Arctic Ocean). Organic Geochemistry 92, 42-54.

De Jonge, C., Talbot, H.M., Bischoff, J., Stadnitskaia, A., Cherkashov, G., Sinninghe Damsté, J.S., 2016b. Bacteriohopanepolyol distribution in Yenisei River and Kara Sea suspended particulate matter and sediments traces terrigenous organic matter input. Geochimica et Cosmochimica Acta 174, 85-101.

De Jonge, C., Stadnitskaia, A., Hopmans, E.C., Cherkashov, G., Fedotov, A., Streletskaya, I.D., Vasiliev, A.A., Sinninghe Damsté, J.S., 2015. Drastic changes in the distribution of branched tetraether lipids in suspended matter and sediments from the Yenisei River and Kara Sea (Siberia): Implications for the use of brGDGT-based proxies in coastal marine sediments. Geochimica et Cosmochimica Acta 165, 200-225.

Doğ rul Selver, A., Sparkes, R.B., Bischoff, J., Talbot, H.M., Gustafsson, Ö., Semiletov, I. P., Dudarev, O.V., Boult, S., van Dongen, B.E., 2015. Distributions of bacterial and archaeal membrane lipids in surface sediments reflect differences in input and loss of terrestrial organic carbon along a cross-shelf Arctic transect. Organic Geochemistry 83-84, 16-26.

Ganzert, L., Bajerski, F., Wagner, D., 2014. Bacterial community composition and diversity of five different permafrost-affected soils of Northeast Greenland. FEMS Microbiology Ecology 89, 426-441.

Gittel, A., Bárta, J., Kohoutová, I., Mikutta, R., Owens, S., Gilbert, J., Schnecker, J., Wild, B., Hannisdal, B., Maerz, J., Lashchinskiy, N., Čapek, P., Šantrůčková, H., Gentsch, N., Shibistova, O., Guggenberger, G., Richter, A., Torsvik, V.L., Schleper, C., Urich, T., 2014. Distinct microbial communities associated with buried soils in the Siberian tundra. The ISME Journal 8, 841-853.

Günther, F., Overduin, P.P., Makarov, A., Grigoriev, M.N., 2013. Russian-German cooperation SYSTEM LAPTEV SEA: the Expeditions Laptev Sea - Mamontov Klyk 2011 \& Buor Khaya 2012. Berichte zur Polar- und Meeresforschung, Bremerhaven, Alfred Wegener Institute for Polar and Marine Research 664, 113 p., https://doi.org/10.2312/BzPM_0664_2013.

Hammer, Ø., Harper, D., Ryan, P.D., 2001. PAST: paleontological statistics software package for education and data analysis. Palaeontologia Electronica 4 (1), 9 pp.

Hanna, A.J.M., Shanahan, T.M., Allison, M.A., 2016. Distribution of branched GDGTs in surface sediments from the Colville River, Alaska: Implications for the MBT' CBT paleothermometer in Arctic marine sediments. Journal of Geophysical Research, Biogeosciences 121, 1762-1780.

Hinsa-Leasure, S.M., Bhavaraju, L., Rodrigues, J.L.M., Bakermans, C., Gilichinsky, D.A., Tiedje, J.M., 2010. Characterization of a bacterial community from a Northeast Siberian seacoast permafrost sample. FEMS Microbiology Ecology 74, 103-113.

Ho, S.L., Mollenhauer, G., Fietz, S., Martínez-Garcia, A., Lamy, F., Rueda, G., Schipper, K., Méheust, M., Rosell-Mele, A., Stein, R., Tiedemann, R., 2014. Appraisal of TEX86 and thermometries in subpolar and polar regions. Geochimica et Cosmochimica Acta 131, 213-226.

Höfle, S.T., Kusch, S., Talbot, H.M., Mollenhauer, G., Zubrzycki, S., Burghardt, S., Rethemeyer, J., 2015. Characterisation of bacterial populations in Arctic permafrost soils using bacteriohopanepolyols. Organic Geochemistry 88, 1-16.

Hong, J.-K., Cho, J.-C., 2015. Environmental variables shaping the ecological niche of thaumarchaeota in soil: direct and indirect causal effects. PLoS ONE 10, e0133763-e133820. https://doi.org/10.1371/journal.pone.0133763.

Hopmans, E.C., Schouten, S., Sinninghe Damsté, J.S., 2016. The effect of improved chromatography on GDGT-based palaeoproxies. Organic Geochemistry 93, 1-6.

Hopmans, E.C., Weijers, J.W.H., Schefuß, E., Herfort, L., Sinninghe Damsté, J.S., Schouten, S., 2004. A novel proxy for terrestrial organic matter in sediments based on branched and isoprenoid tetraether lipids. Earth and Planetary Science Letters 224, 107-116.

Hugelius, G., Strauss, J., Zubrzycki, S., Harden, J.W., Schuur, E.A.G., Ping, C.L., Schirrmeister, L., Grosse, G., Michaelson, G.J., Koven, C.D., O’Donnell, J.A., Elberling, B., Mishra, U., Camill, P., Yu, Z., Palmtag, J., Kuhry, P., 2014. Improved estimates show large circumpolar stocks of permafrost carbon while quantifying substantial uncertainty ranges and identifying remaining data gaps. Biogeosciences 11, 4771-4822.

Huguet, C., Hopmans, E.C., Febo-Ayala, W., Thompson, D.H., Sinninghe Damsté, J.S. Schouten, S., 2006. An improved method to determine the absolute abundance of glycerol dibiphytanyl glycerol tetraether lipids. Organic Geochemistry 37, 1036-1041.

Isoda, R., Hara, S., Tahvanainen, T., Hashidoko, Y., 2017. Comparison of Archaeal Communities in Mineral Soils at a Boreal Forest in Finland and a ColdTemperate Forest in Japan. Microbes and Environments 32, 390-393.

Kim, H.M., Jung, J.Y., Yergeau, E., Hwang, C.Y., Hinzman, L., Nam, S., Hong, S.G., Kim, O.-S., Chun, J., Lee, Y.K., 2014. Bacterial community structure and soil properties of a subarctic tundra soil in Council, Alaska. FEMS Microbiology Ecology 89, 465-475.

Jansson, J.K., Taş, N., 2014. The microbial ecology of permafrost. Nature Reviews Microbiology 12, 414-425.

Leininger, S., Urich, T., Schloter, M., Schwark, L., Qi, J., Nicol, G.W., Prosser, J.I., Schuster, S.C., Schleper, C., 2006. Archaea predominate among ammoniaoxidizing prokaryotes in soils. Nature Reviews Microbiology 442, 806-809.

Liebner, S., Harder, J., Wagner, D., 2008. Bacterial diversity and community structure in polygonal tundra soils from Samoylov Island, Lena Delta, Siberia. International Microbiology 11, 195-202.

Männistö, M.K., Tiirola, M., Häggblom, M.M., 2007. Bacterial communities in Arctic fjelds of Finnish Lapland are stable but highly pH-dependent. FEMS Microbiology Ecology 59, 452-465.

Naafs, B.D.A., Inglis, G.N., Zheng, Y., Amesbury, M.J., Biester, H., Bindler, R., Blewett, J., Burrows, M.A., del Castillo Torres, D., Chambers, F.M., Cohen, A.D., Evershed, R.P., Feakins, S.J., Gałka, M., Gallego-Sala, A., Gandois, L., Gray, D.M., Hatcher, P. G., Coronado, E.N.H., Hughes, P.D.M., Huguet, A., Könönen, M., Laggoun-Défarge, F., Lähteenoja, O., Lamentowicz, M., Marchant, R., McClymont, E., PontevedraPombal, X., Ponton, C., Pourmand, A., Rizzuti, A.M., Rochefort, L., Schellekens, J., De Vleeschouwer, F., Pancost, R.D., 2017. Introducing global peat-specific temperature and $\mathrm{pH}$ calibrations based on brGDGT bacterial lipids. Geochimica et Cosmochimica Acta 208, 285-301.

Nicol, G.W., Leininger, S., Schleper, C., Prosser, J.I., 2008. The influence of soil pH on the diversity, abundance and transcriptional activity of ammonia oxidizing archaea and bacteria. Environmental Microbiology 10, 2966-2978.

Overduin, P.P., 2015. Pore water geochemistry of sediment core BK-8. Alfred Wegener Institute - Research Unit Potsdam. PANGAEA, https://doi.org/10.1594/ PANGAEA.847262.

Peterse, F., Kim, J.-H., Schouten, S., Kristensen, D.K., Koç, N., Sinninghe Damsté, J.S. 2009. Constraints on the application of the MBT/CBT palaeothermometer at high latitude environments (Svalbard, Norway). Organic Geochemistry 40, 692 699.

Peterse, F., Vonk, J.E., Holmes, R.M., Giosan, L., Zimov, N., Eglinton, T.I., 2014 Branched glycerol dialkyl glycerol tetraethers in Arctic lake sediments: Sources and implications for paleothermometry at high latitudes. Journal of Geophysical Research, Biogeosciences 119, 1738-1754.

Pitcher, A., Rychlik, N., Hopmans, E.C., Spieck, E., Rijpstra, W.I.C., Ossebaar, J., Schouten, S., Wagner, M., Sinninghe Damsté, J.S., 2010. Crenarchaeol dominates the membrane lipids of Candidatus Nitrososphaera gargensis, a thermophilic Group I.1b Archaeon. The ISME Journal 4, 542-552.

Prosser, J.I., Nicol, G.W., 2012. Archaeal and bacterial ammonia- oxidisers in soil: the quest for niche specialisation and differentiation. Trends in Microbiology 20, $523-531$.

Rivkina, E.M., Friedmann, E.I., McKay, C.P., Gilichinsky, D.A., 2000. Metabolic activity of permafrost bacteria below the freezing point. Applied and Environment Microbiology 66, 3230-3233.

Rivkina, E., Laurinavichius, K., McGrath, J., Tiedje, J., Shcherbakova, V., Gilichinsky, D., 2004. Microbial life in permafrost. Advances in Space Research 33, 12151221.

Rivkina, E., Shcherbakova, V., Laurinavichius, K., Petrovskaya, L., Krivushin, K., Kraev, G., Pecheritsina, S., Gilichinsky, D., 2007. Biogeochemistry of methane and methanogenic archaea in permafrost. FEMS Microbiology Ecology 61, $1-15$.

Schirrmeister, L., Grosse, G., Schnelle, M., Fuchs, M., Krbetschek, M., Ulrich, M., Kunitsky, V., Grigoriev, M., Andreev, A., Kienast, F., Meyer, H., Babiy, O., Klimova, I., Bobrov, A., Wetterich, S., Schwamborn, G., 2011a. Late Quaternary paleoenvironmental records from the western Lena Delta, Arctic Siberia. Palaeogeography, Palaeoclimatology, Palaeoecology 299, 175-196.

Schirrmeister, L., Kunitsky, V., Grosse, G., Wetterich, S., Meyer, H., Schwamborn, G. Babiy, O., Derevyagin, A., Siegert, C., 2011b. Sedimentary characteristics and origin of the Late Pleistocene Ice Complex on north-east Siberian Arctic coastal lowlands and islands - A review. Quaternary International 241, 3-25.

Schirrmeister, L., Schwamborn, G., Overduin, P.P., Strauss, J., Fuchs, M.C., Grigoriev, M., Yakshina, I., Rethemeyer, J., Dietze, E., Wetterich, S., 2017. Yedoma Ice Complex of the Buor Khaya Peninsula (southern Laptev Sea). Biogeosciences 14, $1261-1283$.

Schouten, S., Hopmans, E.C., Schefuß, E., Sinninghe Damsté, J.S., 2002. Distributional variations in marine crenarchaeotal membrane lipids: a new tool for reconstructing ancient sea water temperatures? Earth \& Planetary Sciences Letters 204, 265-274.

Schouten, S., Hopmans, E.C., Sinninghe Damsté, J.S., 2013. The organic geochemistry of glycerol dialkyl glycerol tetraether lipids: A review. Organic Geochemistry 54, 19-61. 
Schwamborn, G., Rachold, V., Grigoriev, M.N., 2002. Late Quaternary sedimentation history of the Lena Delta. Quaternary International 89, 119-134.

Schwamborn, G., Wetterich, S., 2016. Sample list and field descriptions of the L14 profiles studied in summer 2014. PANGAEA. https://doi.org/10.1594/ PANGAEA.859305.

Schwamborn, G., Wetterich, S., 2015. Russian-German cooperation CARBOPERM: field campaigns to Bol'shoy Lyakhovsky Island in 2014. Berichte zur Polar- und Meeresforschung, Bremerhaven, Alfred Wegener Institute for Polar and Marine Research 686, 100 p., doi: 10.2312/BzPM_0686_2015.

Shcherbakova, V., Yoshimura, Y., Ryzhmanova, Y., Taguchi, Y., Segawa, T. Oshurkova, V., Rivkina, E., 2016. Archaeal communities of Arctic methanecontaining permafrost. FEMS Microbiology Ecology 92, fiw135. https://doi.org/ $10.1093 /$ femsec/fiw135.

Sinninghe Damsté, J.S., Rijpstra, W.I.C., Foesel, B.U., Huber, K.J., Overmann, J. Nakagawa, S., Kim, J.J., Dunfield, P.F., Dedysh, S.N., Villanueva, L., 2018. An overview of the occurrence of ether- and ester-linked iso-diabolic acid membrane lipids in microbial cultures of the Acidobacteria: Implications for brGDGT paleoproxies for temperature and pH. Organic Geochemistry 124, $63-76$.

Sinninghe Damsté, J.S., 2016. Spatial heterogeneity of sources of branched tetraethers in shelf systems: The geochemistry of tetraethers in the Berau River delta (Kalimantan, Indonesia). Geochimica et Cosmochimica Acta 186, 13-31.

Sinninghe Damsté, J.S., Rijpstra, W.I.C., Hopmans, E.C., Foesel, B.U., Wüst, P.K. Overmann, J., Tank, M., Bryant, D.A., Dunfield, P.F., Houghton, K., Stott, M.B. 2014. Ether- and ester-bound iso-diabolic acid and other lipids in members of acidobacteria subdivision 4. Applied and Environment Microbiology 80, 5207 5218.

Sinninghe Damsté, J.S., Rijpstra, W.I.C., Hopmans, E.C., Jung, M.Y., Kim, J.G., Rhee, S K., Stieglmeier, M., Schleper, C., 2012. Intact polar and core glycerol dibiphytanyl glycerol tetraether lipids of group I.1a and I.1b thaumarchaeota in soil. Applied and Environment Microbiology 78, 6866-6874.

Sinninghe Damsté, J.S., Rijpstra, W.I.C., Hopmans, E.C., Weijers, J.W.H., Foesel, B.U. Overmann, J., Dedysh, S.N., 2011. 13,16-Dimethyl octacosanedioic acid (isodiabolic acid), a common membrane-spanning lipid of Acidobacteria subdivisions 1 and 3. Applied and Environment Microbiology 77, 4147-4154.

Sparkes, R.B., Doğrul Selver, A., Bischoff, J., Talbot, H.M., Gustafsson, Ö., Semiletov, P. Dudarev, O.V., van Dongen, B.E., 2015. GDGT distributions on the East Siberian Arctic Shelf: implications for organic carbon export, burial and degradation. Biogeosciences 12, 3753-3768.

Stapel, J.G., Schwamborn, G., Schirrmeister, L., Horsfield, B., Mangelsdorf, K., 2018. Substrate potential of Eemian to Holocene permafrost organic matter for future microbial greenhouse gas production. Biogeosciences 15, 1969-1985.

Stapel, J.G., Schirrmeister, L., Overduin, P.P., Wetterich, S., Strauss, J., Horsfield, B. Mangelsdorf, K., 2016. Microbial lipid signatures and substrate potential of organic matter in permafrost deposits - implications for future greenhouse gas production. Journal of Geophysical Research, Biogeosciences 121. https://doi. org/10.1002/2016JG003483.

Steven, B., Niederberger, T.D., Bottos, E.M., Dyen, M.R., Whyte, L.G., 2007 Development of a sensitive radiorespiration method for detecting microbia activity at subzero temperatures. Journal of Microbiological Methods 71, 275280.

Stieglmeier, M., Klingl, A., Alves, R.J.E., Rittmann, S.K.-M.R., Melcher, M., Leisch, N. Schleper, C., 2014. Nitrososphaera viennensis gen. nov., sp. nov., an aerobic and mesophilic, ammonia-oxidizing archaeon from soil and a member of the archaeal phylum Thaumarchaeota. International Journal of Systematic and Evolutionary Microbiology 64, 2738-2752.

Thienemann, M., Masi, A., Kusch, S., Sadori, L., John, S., Francke, A., Wagner, B. Rethemeyer, J., 2017. Organic geochemical and palynological evidence for
Holocene natural and anthropogenic environmental change at Lake Dojran (Macedonia/Greece). The Holocene 27, 1103-1114.

Tripathi, B.M., Kim, M., Kim, Y., Byun, E., Yang, J.-W., Ahn, J., Lee, Y.K., 2018. Variations in bacterial and archaeal communities along depth profiles of Alaskan soil cores. Scientific Reports. https://doi.org/10.1038/s41598-01718777-x.

Tuorto, S.J., Darias, P., McGuinness, L.R., Panikov, N., Zhang, T., Häggblom, M.M., Kerkhof, L.J., 2014. Bacterial genome replication at subzero temperatures in permafrost. The ISME Journal 8, 139-149.

van Dongen, B.E., Semiletov, I., Weijers, J.W.H., Gustafsson, Ö., 2008. Contrasting lipid biomarker composition of terrestrial organic matter exported from across the Eurasian Arctic by the five great Russian Arctic rivers. Global Biogeochemical Cycles 22, GB1011. https://doi.org/10.1029/2007GB002974.

Verhamme, D.T., Prosser, J.I., Nicol, G.W., 2011. Ammonia concentration determines differential growth of ammonia-oxidising archaea and bacteria in soil microcosms. The ISME Journal 5, 1067-1071.

Weber, E.B., Lehtovirta-Morley, L.E., Prosser, J.I., Gubry-Rangin, C., 2015. Ammonia oxidation is not required for growth of Group 1.1c soil Thaumarchaeota. FEMS Microbiology Ecology 91, 182-187.

Weijers, J.W.H., Lim, K.L.H., Aquilina, A., Sinninghe Damsté, J.S., Pancost, R.D., 2011. Biogeochemical controls on glycerol dialkyl glycerol tetraether lipid distributions in sediments characterized by diffusive methane flux. Geochemistry, Geophysics, Geosystems 12, Q10010. https://doi.org/10.1029/ 2011GC003724.

Weijers, J.W.H., Schouten, S., Spaargaren, O.C., Sinninghe Damsté, J.S., 2006. Occurrence and distribution of tetraether membrane lipids in soils: Implications for the use of the TEX86 proxy and the BIT index. Organic Geochemistry 37, 1680-1693.

Weijers, J.W.H., Schouten, S., van den Donker, J.C., Hopmans, E.C., Sinninghe Damsté, J.S., 2007. Environmental controls on bacterial tetraether membrane lipid distribution in soils. Geochimica et Cosmochimica Acta 71, 703-713.

Weijers, J.W.H., Wiesenberg, G.L.B., Bol, R., Hopmans, E.C., Pancost, R.D., 2010. Carbon isotopic composition of branched tetraether membrane lipids in soils suggest a rapid turnover and a heterotrophic life style of their source organism (s). Biogeosciences 7, 2959-2973.

Wilhelm, R.C., Niederberger, T.D., Greer, C., Whyte, L.G., 2011. Microbial diversity of active layer and permafrost in an acidic wetland from the Canadian High Arctic. Canadian Journal of Microbiology 57, 303-315.

Willerslev, E., Hansen, A.J., Rønn, R., Brand, T.B., Barnes, I., Wiuf, C., Gilichinsky, D., Mitchell, D., Cooper, A., 2004. Long-term persistence of bacterial DNA. Current Biology 14, R9-R10. https://doi.org/10.1016/j.cub.2003.12.012.

Zhang, Y.G., Zhang, C.L., Liu, X.-L., Li, L., Hinrichs, K.-U., Noakes, J.E., 2011. Methane Index: A tetraether archaeal lipid biomarker indicator for detecting the instability of marine gas hydrates. Earth and Planetary Science Letters 307, 525-534.

Zhou, J.Z., Davey, M.E., Figueras, J.B., Rivkina, E., Gilichinsky, D., Tiedje, J.M., 1997. Phylogenetic diversity of a bacterial community determined from Siberian tundra soil DNA. Microbiology 143, 3913-3919.

Zimmermann, H.H., Raschke, E., Epp, L.S., Stoof-Leichsenring, K.R., Schirrmeister, L., Schwamborn, G., Herzschuh, U., 2017a. The history of tree and shrub taxa on Bol'shoy Lyakhovsky Island (New Siberian Archipelago) since the last interglacial uncovered by sedimentary ancient DNA and pollen data. Genes 8 (10), E273. https://doi.org/10.3390/genes8100273.

Zimmermann, H.H., Raschke, E., Epp, L.S., Stoof-Leichsenring, K.R., Schwamborn, G. Schirrmeister, L., Overduin, P.P., Herzschuh, U., 2017b. Sedimentary ancient DNA and pollen reveal the composition of plant organic matter in Late Quaternary permafrost sediments of the Buor Khaya Peninsula (north-eastern Siberia). Biogeosciences 14, 575-596. 